\title{
THE EFFECT OF COVID-19 PANDEMIC ON MACROECONOMIC STABILITY IN ETHIOPIA
}

(Uncertainty Shock Impact, Transmission Mechanism and the Role of Fiscal

Policy)

\section{Habtamu Girma Demiessie ${ }^{1}$}

August, 2020

Jigjiga, Ethiopia

${ }^{1}$ Assistant Professor of Economic Policy Analysis at Jigjiga University (JJU), Ethiopia. He can be reached at Email: ruhe215@gmail.com or hab200517@yahoo.com 


\section{Acknowledgment}

The author would like to extend his sincere regard to Jigjiga University Vice President Office for Research and Community Service (JJU-VPRCS) for financing this study. A special gratitude goes to my colleagues at JJU-VPRCS: Dr. Tesfu Mengistu, Dr. Elyas Abdulahi, Mr. Muyhedin Mohammed, Dr. Solomon Yared and Dr. Binyam Bogale for their amenable managerial services from the very start of the study. I also owe my friend Mr. Miler Teshome, whose encouragement was a positive energy in the process of undertaking the research. I also benefited from Mr. Wubeshet Gezahegne and Mr. Moges Tufa, who unreservedly extended their professional expertise in reviewing the manuscript to come up with invaluable comments and suggestions 


\begin{abstract}
This study investigated the impact of COVID-19 pandemic uncertainty shock on the macroeconomic stability in Ethiopia in the short run period. The World Pandemic Uncertainty Index (WPUI) was used a proxy variable to measure COVID-19 Uncertainty shock effect. The pandemic effect on core macroeconomic variables like investment, employment, prices (both food \& non-food prices), import, export and fiscal policy indicators was estimated and forecasted using Dynamic Stochastic General Equilibrium (DSGE) Model. The role of fiscal policy in mitigating the shock effect of coronavirus pandemic on macroeconomic stability is also investigated.
\end{abstract}

The finding of the study reveals that the COVID-19 impact lasts at least three years to shake the economy of Ethiopia. Given that the Ethiopian economy heavily relies on import to supply the bulk of its consumption and investment goods, COVID-19 uncertainty effect starts as supply chain shock, whose effect transmitted into the domestic economy via international trade channel. The pandemic uncertainty shock effect is also expected to quickly transcend to destabilize the economy via aggregate demand, food \& non-food prices, investment, employment and export shocks.

The VAR estimate indicates that COVID-19 uncertainty shock results a massive rise in import in the six months following the outbreak of the pandemic. The finding in this regard is expected, as the pandemic triggers massive demand in food and pharmaceuticals, for which Ethiopia is import dependent on both items. In the next two years, however, the import bill of Ethiopia shows a decline. Reduction in aggregate demand (both consumption \& investment expenditures) is one explanation for decline in import size in 2013 and 2014 E.C.

The price dynamics as forecasted in the upcoming three years in Ethiopia tells the direction of impacts of COVID-19 uncertainty shock to shake the macroeconomic order. The findings in this regard revealed the structural breakups of Ethiopian economy, characterized by its inability to withstand shocks. As signaled in forecasted price dynamics on both food and non-food price indices, COVID-19 was a supply shock in its first time impact, but quickly trans-passes to demand shock. And in the next few years the demand shock outweighs the supply shock. 
The results of estimations indicate that food prices to sky rocketed at least until the end of 2014 E.C (2021/22 E.F.Y). On the other hand, except communication \& hotel \& restaurant prices, other components of non-food price indices show a slump. The decline in non-food price level is a clear showcase of under-consumption characterizes the economic order in Ethiopia in the coming three years.

COVID-19 uncertainty shock puts huge loss in the investment sector in Ethiopia at least in the coming two years 2013 and 2014 E.C (2020/21-2021/22). In this regard, the pandemic effect transmitted to shake investment expenditure via the length of the pandemic period itself and export performances, both of which are exogenous shocks.

The study identified that general under consumption features the Ethiopian economy in the next couple of years. Therefore, the government is expected to enact incentives/policy directions which can boost business confidence. A managed expansionary fiscal policy is found to be key to promote investment, employment and to stabilize food \& non-food prices. A particular role of fiscal policy was identified to stabilizing food, transport and communication prices. More importantly, price stabilization policies of the government can have spillover effects in boosting aggregate demand by spurring investments (and widening employment opportunities) in transport/logistics, hotel \& restaurant, culture \& tourism and export sectors in particular. 


\section{INTRODUCTION}

\subsection{Background \& Justification}

Quiet unprecedented in the world history in memory, all corners of the globe is living at a standstill following the outbreak of coronavirus pandemic. A highly contagious viral disease, Cvid-19 (the scientific name of the disease) has stopped virtually every human activity at global scale, as people`s movement curbed;; by way of controlling the spread of the pandemic (Fetzer, T. et al, March 2020, Politico, March 19/2020).

Expertise commentaries on Covid-19 dub the disease an economic pandemic, to signify counting the cost of the cure is getting dear than the problem itself. The size of the shock will be determined mostly by the measures taken to avoid large scale contagion and to limit the area of spread. Thus, the containment measures - the disruption to work processes, the limitations on meetings and travel - will be a larger negative supply shock than the number of deaths, even if the latter could still turn out to be large. Full or partial lockdown, like in China, is one of the most extreme measures and can bring production and consumption almost to a standstill. Such extreme measures are likely to remain restricted to certain areas and will be difficult to maintain for a long time (Baldwin, R. and Weder di Mauro, B., 2020).

On the most extreme case, the economic cost of COVID-19 to the world is predicted to be close 2.5 trillion USD, a size of GDP of Britain. The global financial market is also losing massively day by day. As has been reported from the world stoke exchange markets, the three weeks of damages of covid-19 is even worse than the three years of great depression of 1930`s, and the 2008 financial crisis (later economic crisis) (Bloomberg Economic Study).

While those costs are incurred at the starting days of the outbreak, one can imagine how the cost would surge as corona-days count. In the years after the pandemic, the world has to expect the biggest economic challenge ever. African economies already small enough to shake by the shocks of global economy, the continent should also prepare for the worst economic hit (Africa News, March 31/2020; REUTERS, March 24/2020). 
For many analysts, COVID-19 is dismantling not just the economy, but also changing the way all sorts of human transactions hold, locally and globally. Indeed we are witnessing COVID-19`s staggering impacts in changing the way political business functions; also in its effect of reshaping intra-personal \& inter-personal communications too. Scholars are also predicting for its impact in restructuring the global order by triggering for global actions forward, something the world has been missing in the past decades or so.( Politico, March 19/2020)

Ethiopia announced the first case of coronavirus on March 13 2020. Since then Coronavirus has taken the single most topic grabbing the dialogue among the Ethiopian society. The government of Ethiopia has also considered the issue a number one national agenda, where a number of measures and actions taken to fight the spread of the disease. (Africa News, REUTERS)

In a bid to curb the spread of the disease thereby limiting the movement of people, the government announced for schools \& universities to shut-down; also large portion of personnel in the public service were set to stay home.

So far, the government of Ethiopia has allotted 5 billion birr for expenses on COVID-19 emergency activities. The private \& public sector entities, and the general public have also been contributing in terms of monetary capital, equipment and residential also in response to the national call for assistances as waged by the government of Ethiopia later March/2020 (FBC).

While massive actions and many actors are preparing for the inevitable war against the coronavirus in Ethiopia, it is also wise to set aside resources to make for life after COVID-19. As we note from history, deadly pandemics are inherent to human civilizations, where disease outbreaks comes and go leaving their legacies \& scars. The same holds to COVID-19 too. Hence, while mobilizing all our efforts to the inevitable war, it also important to design how we may ease the hard times we are awaited after COVID-19.

At least at this point in time, COVID-19 is much a media issue than an academic topic. In fact the problem is newer and it takes time to deal it with empirics, but that does not mean there is no scope for academic interventions. Indeed, the academic circle can (should) look the matter on table for expertise treatise, and come up with sound way forward that can be used by governments in the fight against coronavirus. 
So far pioneering works on the topic were undertaken by think thank groups and professional institutions working in Ethiopia. In this regard, the policy researches by Ethiopian Economics Association and Policy Institute has produced two policy papers on COVID-19 economic wide impact on Ethiopia. A study by $\mathrm{EEA}^{2}$, titled, The economy wide impact of the COVID-19 in Ethiopia: Policy and Recovery options', investigated the short, medium and long term impacts of COVID-19 on the Ethiopian economy. Using a dynamic Computable Equilibrium (CGE) model, the study captured the impact of the pandemic on productivity growth of labor and capital the impacts on Foreign Direct Investments and Remittances, export demand, import supply, transaction costs and the anticipated government interventions. The study reported the pandemic effect under mild and severe case scenario. Accordingly, under amplified (or severe) pandemic scenario, the total loss on the economy as a result of COVID-19 shock is estimated at 310 billion birr in FY 2020/21, whose effect downgraded the forecast estimate on economic growth in $2020 / 21$ to $0.6 \%{ }^{3}$.

A study by FDRE Policy Institute (PI) aimed at identifying key policy alternatives to tackle the social and economic impacts of CIVID-19 on Ethiopia. An exploratory study investigated determinant factors on effectiveness and implications of public health measures aimed at mitigating the effect of COVID-19. Accordingly, factors related to demographic, economic and social settings are important in determining the economic damages associated with the public health measures to contain or suppress the virus. The study recommended targeted and combined social and economic policy measures to overcome COVID - 19 effects on the economy ${ }^{4}$.

Another policy research, which was authored by Alemayehu Geda ${ }^{5}$, investigated the dynamic impact of the pandemic on the Ethiopian economy. Using auto-regressive distribution lag model (ADL) model, the study focused on the COVID-19 effect on the service sector of Ethiopia.

Finding from this study reveal that a ten percent increase in confirmed weekly cases in Ethiopia is found to lead to a 1.1 and 6.8 percent reduction in demand for hotels in the long and short run, respectively This reduction becomes $8.5 \%$ and $3.7 \%$ for restaurants and air travel services in the short run. The study further estimated that demand for services in the tourism sector to decline

${ }^{2}$ Tadele Ferede, Getachew Diriba and Lulit Mitik Beyene. 2020

${ }^{3}$ The pre-pandemic growth projection for Ethiopian economy was $9 \%$ in the year 2020/21.

${ }_{5}^{4}$ Alebel Bayrau Weldesilassie and Tassew Woldehanna. 2020.

${ }^{5}$ Alemayehu Geda. 2020 
by about 15 to 17 percent for a ten percent increase in confirmed weekly cases in the short run. In the other hand, the estimation from the study indicated COVID-19 shock results in an increase in the demand for communication services, where a $10 \%$ increase in weekly cases estimated to increase the demand for Zoom software demand (a proxy variable to communication service) by 5.6 percent both in the short run and the long run.

Empirical evidences so far on the effect of COVID-19 on Ethiopian economy did not address the dynamic impact through the channel of uncertainty impact of the pandemic on macroeconomic stability. Therefore, this study tries to fill this gap. As such, analysis and inferences were made on COVID-19 uncertainty shock effect on the pillars of macroeconomic stability: Investment, Employment, Export expenditure, Import demand, Price Indices (both food and Non-Food prices) and Government Expenditures. Moreover, the role of fiscal policy to mitigate the effect of the pandemic in the short run period is also investigated.

\subsection{Objectives}

The general objective of this study is to identify, measure and interpret the impact of COVID-19 uncertainty shock on the macroeconomic stability in Ethiopia in the short run.।

\section{Specific Objectives}

- Diagnose into the transmission mechanism of the COVID-19 uncertainty shock effect into the Ethiopian economy

- Estimate and forecast uncertainty shock effect on real variables in the macroeconomic order: Investment expenditure, export, import, food \& non-food prices, level of employment and government expenditure.

- Investigate the role of fiscal policy measures to ease the potential shock effects of COVID-19 pandemic on macroeconomic instability

\subsection{Significance of the Study}

This study can provide valuable evidences for macroeconomic policy interventions aimed at mitigating the shock effects of coronavirus pandemic on Ethiopian economy in the short run period. The significance of the study can also be in invigorating expert discussions and/or initiating further inquiry on the subject. 


\section{METHODOLOGY OF THE STUDY}

This part of the study locates on key methodological elements that the study used while making analysis and inferences pertaining to its objectives already defined under chapter one. The core aspects subject of discussions of this section would be the following two components of analysis and inferences:

- Data Sources, tools and Techniques of Data Collection

- Method of analysis and Inference

\subsection{Data Types, Data Sources and Tools of Data Collection}

As the study encompasses both qualitative and quantitative elements, the data used to draw inferences were based on qualitative and quantitative data sources.

\subsubsection{Primary Data}

Qualitative aspect of the study relied on inferences made from primary sources. Key primary sources sought were expert analytics given for media outlets (both local \& international) on the impact of Covid-19 on Ethiopian and the African economy. The author also underwent in-depth interviews from senior economists at the helms of economic research and economic policy on Ethiopia.

\subsubsection{Secondary Data Sources}

The quantitative aspect of this study used datasets gathered from secondary data sources. The secondary sources of study are latest reports on Ethiopian economy from broader local and international sources: Like National Bank of Ethiopia (NBE), Ethiopian Development Research Institute, Ethiopian economics Association, Ministry of Finance and Economic Cooperation (MoFEC), Ethiopian Planning Commission, among others.

\subsection{Conceptual Framework and Techniques of Analysis and Inferences}

The study integrates both qualitative and quantitative techniques to analyze the data and make inferences. The whole set of analysis and inference made in this study relies on circular flow of economy. For this study, linkage in economic sectors/factors of productions/agents is based on 
framework of World Bank Group that was used to construct the latest Input-output Matrix or SAM matrix for Ethiopia (Andualem et al, 2020)

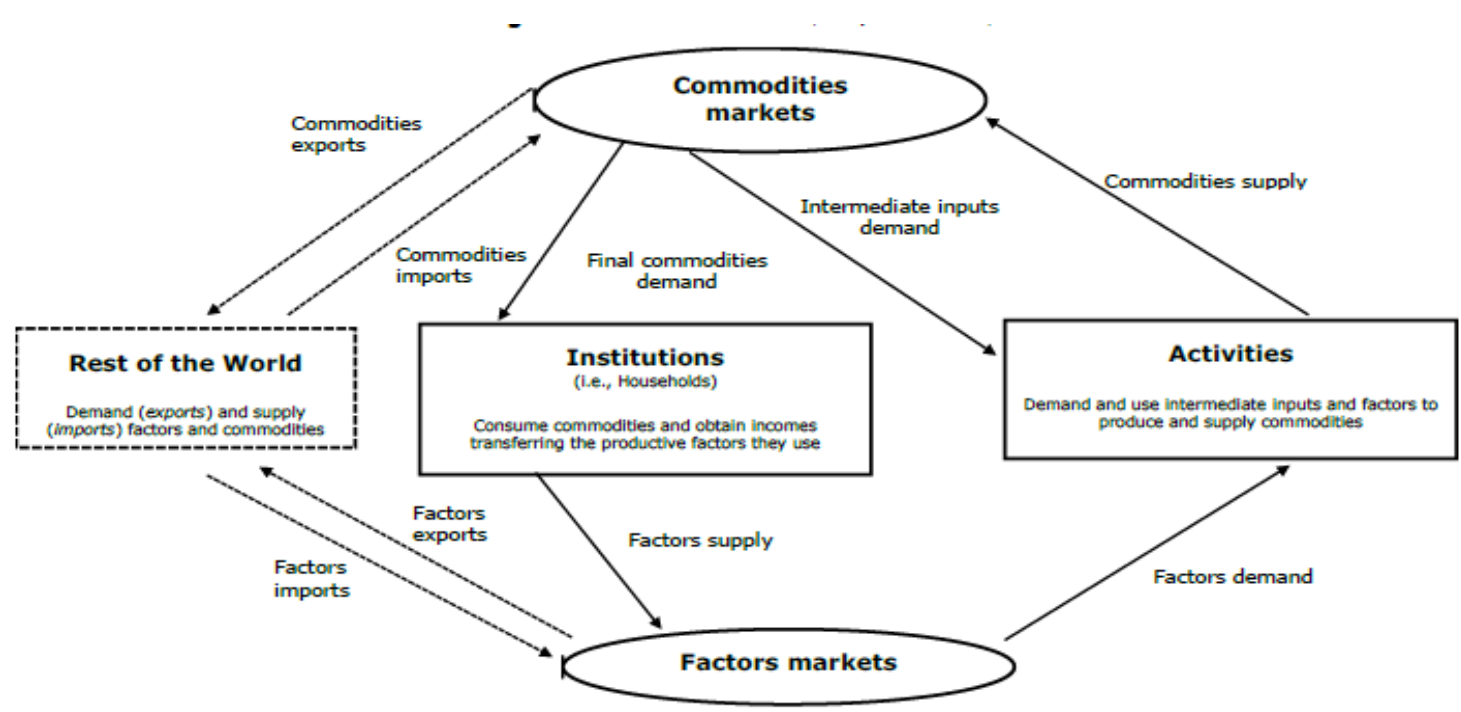

Figure 1: $\quad$ The Transmission Mechanism of COVID-19 Uncertainty shock

\subsection{Techniques of Analysis and Inferences}

The study employs both descriptive and econometrics techniques to analyze the data. The study relies on the essentials of macroeconomic policy approach to draw of inferences to best address the core objectives outlined. As such, narratives integrate positive and normative approach while making analysis and inferences. Positive approach of making analysis involves making a diagnostic look on the scale of damage of COVID-19 uncertainty shock on Ethiopian economy. The normative aspect of analysis is meant to propose a viable policy options to mitigate the macroeconomic instabilities as result of the pandemic shock effect.

By way of organizing and reporting the results of data analysis, the study adopted a framework proposed by UNCTAD (2020) and UN-ECA (2020) (UNCTD, 202). Accordingly, narratives on impact of COVID-19 on the Ethiopian economy are analyzed on three dimensions: The Domestic Sector, The Foreign Sector and the policy circle. 


\section{Econometrics Model}

To estimate on the seize and dimensions of effect of COVID-19 shock on macroeconomic stability, the study relied on Dynamic stochastic general equilibrium models (DSGE) or Bayesian Vector Auto-regressions (BVAR).

Bayesian Vector Auto-regressions (VARs) are linear multivariate time-series models able to capture the joint dynamics of multiple time series (Miranda-Agrippin, S. and Ricco, G.; 2018) The earliest studies employing Bayesian VARs (BVARs) to macroeconomic forecasting are found in Letterman (1979) and Doan et al. (1984) Since then, VARs and BVARs have been a standard macro-econometric tool routinely used by scholars and policy makers for structural analysis, forecasting and scenario analysis in an ever growing number of applications.

Empirical evidences on the uncertainty shock effect of COVID-19 on macroeconomic stability increasingly suggest Dynamic stochastic general equilibrium models (DSGE) or BVAR produces produce sound results (For instance see Leduc and Liu (2020); Watanabe (2020); Ozili (2020) and PINSHI (2020); Alemayehu G. (2020); Kiku, Oscar (2020)

The BVAR model to be estimated in this study is defined as follows:

$$
X t=\sum_{t=1}^{44}\left(\beta_{i} x_{t-i}+\varepsilon\right)
$$

\section{Where:}

$X t=$ Vector of Macroeconomic \& Fiscal Policy Indicators and World Pandemic Uncertainty Index (WPUI)

$\mathcal{E}=$ Vector of residuals of reduced form at time $\mathrm{t}$. 


\subsubsection{Definition of Model Variables}

The COVID-19 first time shock and uncertainty shock is estimated and forecasted using data on core macroeconomic variables defined in the preceding section. Time series data set consists 46 quarters (Qs), where data on macroeconomic variables gathered spanning in the period between 2008/09 Q1 and 2019/20 Q2 was considered. In time series regressions, high frequency data set is preferred over low frequency data set is preferred because to remove seasonality of variables and to reduce the impact of high frequency measurement errors (Baker, Scott R. et al, 2020)

The BVAR model is structured by variables indicating all aspects of the economy: the aggregate demand, aggregate supply, Genera Price Level, current account balance, policy and economic uncertainty indicators.

- Aggregate Demand Indicators: Aggregate Investment Expenditure (domestic and foreign direct investments).

- Aggregate Supply Indicators: Employment

- General Price Level Indicators: Food Price Index (CPIF), Non-food Price indices (Transport Prices, Education Prices, Hotel \& Restaurant Prices, Health Prices, Communication Price Indices)

- Current Account Indicators: Export earnings and Import demand (import expenditure)

- Fiscal Policy Indicator: Government Expenditure (sum total of recurrent \& capital expenditures)

- COVID-19 Uncertainty Shock Indicator: the uncertainty impact of COVID-19 is tapped by the World Pandemic Uncertainty Index on Ethiopia (WPUI) as a proxy variable. The data on WPUI is accessed from $\underline{w w w}$.worlduncertainityindex.com. 
Table 1: Definition of Model Variables:

\begin{tabular}{|c|c|c|c|c|c|c|}
\hline S/No & Variable & Definition & Measurement & $($ In E & $\begin{array}{l}\text { Period } \\
\text { Fiscal Year) }\end{array}$ & $\begin{array}{l}\text { Number of } \\
\text { Observations }\end{array}$ \\
\hline 1 & $\begin{array}{l}\text { World Pandemic } \\
\text { Uncertainty Index (WPUI) }\end{array}$ & $\begin{array}{l}\text { A Proxy Measure of CIVID-19 } \\
\text { Uncertainty Shock Impact }\end{array}$ & $\begin{array}{l}\text { The index is constructed by } \\
\text { counting the number of times } \\
\text { a word related to pandemics is } \\
\text { mentioned in the Economist } \\
\text { Intelligence Unit country } \\
\text { reports. Specifically, the index } \\
\text { is the percent of the words } \\
\text { related to pandemic episodes } \\
\text { in EIU country reports, } \\
\text { multiplied by } 1,000 \text {. A higher } \\
\text { number means higher } \\
\text { discussion about pandemics } \\
\text { and vice versa. }\end{array}$ & $\begin{array}{l}\text { 2008/09 Q1- } \\
\text { 2019/20 Q2 }\end{array}$ & \multicolumn{2}{|c|}{$\begin{array}{l}\text { Uncertainty is associated to total count of five } \\
\text { pandemics namely: SARS, Avian Flu, Swine } \\
\text { Flu, MERS, Bird Flu, Ebola and Coronavirus } \\
\text { between 1996Q1 to 2020Q2 }\end{array}$} \\
\hline 2 & Import & $\begin{array}{l}\text { Quarterly Value of Imports, by Major } \\
\text { Commodity Groups }\end{array}$ & In Million Birr & $\begin{array}{l}\text { 2008/09 Q1- } \\
\text { 2019/20 Q2 }\end{array}$ & & \\
\hline 3 & $\begin{array}{l}\text { Non-Food Price Indices } \\
\text { (COMMUNICATION;TRA } \\
\text { NSPORT; EDUCATION; } \\
\text { HEALTH, HOTELREST) }\end{array}$ & $\begin{array}{l}\text { Quarterly National data on selected } \\
\text { Non-Food price indices (selected non- } \\
\text { food prices in this study are: Transport, } \\
\text { communication, education, health, hotel } \\
\text { \& restaurant price indices }\end{array}$ & Indexed & $\begin{array}{l}2008 / 09 \text { Q1- } \\
2019 / 20 \text { Q2 }\end{array}$ & $\begin{array}{l}\text { In Ethiopian } \\
\text { computed on } \\
\text { following list } \\
\text { - Comm } \\
\text { Health } \\
\text { \& cul } \\
\text { Tobact } \\
\text { Housin } \\
\text { Other } \\
\text { Equipr } \\
\text { the Ho }\end{array}$ & $\begin{array}{l}\text { t, non-food price index is } \\
\text { age price index for the } \\
\text { lucts: } \\
\text { on, Transport, Education, } \\
l \text { \& Restaurant, recreation } \\
\text { Alcoholic Beverages and } \\
\text { Clothing \& Foot-wear; } \\
\text { ater, Electricity/Gas and } \\
\text { Furnishings, Household } \\
\text { nd Routine Maintenance of } \\
\text { iscellaneous Goods }\end{array}$ \\
\hline 4 & Food Price Index (CPIF) & $\begin{array}{l}\text { Quarterly National Food Consumer } \\
\text { Price Index, }\end{array}$ & Indexed & $\begin{array}{l}\text { 2008/09 Q1- } \\
\text { 2019/20 Q2 }\end{array}$ & $\begin{array}{l}\text { In Ethiopian } \\
\text { computed on } \\
\text { following list } \\
\text { - } \quad \text { Bread } \\
\text { Food; } \\
\text { Fats; } \\
\text { Honey } \\
\text { Food } \\
\text { Bever }\end{array}$ & $\begin{array}{l}\text { ext, food price index is } \\
\text { rage price index for the } \\
\text { ducts: } \\
\text { Cereals; Meat; Fish \& Sea } \\
\text {, Cheese \& Egg; Oils \& } \\
\text {; Vegetables; Sugar, Jam, } \\
\text { ocolate \& Confectionery; } \\
\text { roducts; Non-Alcoholic } \\
\end{array}$ \\
\hline 5 & Investment (INVST) & $\begin{array}{l}\text { Investment Capital of Domestic and } \\
\text { Foreign Projects Approved by } \\
\text { agriculture, industry, and service } \\
\text { Sectors in the quarter }\end{array}$ & In Million Birr & $\begin{array}{l}\text { 2008/09 Q1- } \\
\text { 2019/20 Q2 }\end{array}$ & & \\
\hline 6 & Export & $\begin{array}{l}\text { Quarterly Value of Exports, by Major } \\
\text { Commodity Groups }\end{array}$ & In Million Birr & $\begin{array}{l}\text { 2008/09 Q1- } \\
\text { 2019/20 Q2 }\end{array}$ & & \\
\hline 7 & $\begin{array}{l}\text { Employment } \\
\text { (EMPLOYPG) }\end{array}$ & $\begin{array}{l}\text { Number of Employment (Permanent } \\
\text { and Temporary) opportunities Created } \\
\text { by Approved Domestic and Foreign } \\
\text { Investment Projects with more than } \\
250,000 \text { birr registered capital in the } \\
\text { quarter }\end{array}$ & In number & $\begin{array}{l}\text { 2008/09 Q1- } \\
\text { 2019/20 Q2 }\end{array}$ & & \\
\hline 9 & $\begin{array}{l}\text { Government Expenditure } \\
\text { (GOVTEXPEND) }\end{array}$ & $\begin{array}{l}\text { Quarterly Government expenditure (on } \\
\text { recurrent \& capital expenditures and } \\
\text { regional transfers) }\end{array}$ & In Millions of Birr & $\begin{array}{l}\text { 2008/09 Q1- } \\
\text { 2019/20 Q2 }\end{array}$ & & \\
\hline
\end{tabular}




\section{Harmonizing the Data Set}

All quarterly dataset but World Pandemic Uncertainty Index (WPUI) was secured from the local sources. In Ethiopian context, there is difference between fiscal year and calendar year. The fiscal year starts in the month of July (HAMLE 1, in Ethiopian Calendar), while calendar year begins in month of September (MESKEREM 1). For obvious reason, fiscal year is considered in the time series dataset. The four quarters of the Ethiopian fiscal year are: Quarter One: July, August and September; Quarter Two: October, November and December; Quarter Three: January, February and March; Quarter Four: April, May and June

Quarterly data on WPUI is secured from foreign sources, based on Gregorian calendar. The months/quarters of the fiscal year as in Gregorian calendar are as follows: Quarter One: January, February and March; Quarter Two: April, May and June; Quarter Three: July, August and September; and Quarter Four: October, November and December.

Hence, the first and last quarters of all data sets on WPUI was customized to Ethiopian fiscal year. As such, in the data used for regression on WPUI variable, observation in the third quarter of 2008 in the Gregorian calendar was taken to hold the first quarter (first observation) of start year for time series data i.e.2008/09. The data on WPUI from the source as i.e.2020 Q1 was taken as the last observation in the data set i.e. 2019/20 Q2 in Ethiopian fiscal year.

All observations on model variables except World Pandemic Uncertainty Index (WPUI) were transformed into logarithmic value before regression was made.

\section{BVAR Statistical Tests}

Before undertaking VAR estimation and prediction, each model variables were subjected to seasonality and Unit Root Tests.

\section{Seasonality Test}

When a time series data is measured for high frequency series, like monthly or quarterly, they may contain pronounced seasonal variations. The seasonal component in time series refers to patterns that are repeated over a period and that average out in the long run. The patterns that do not average out are included in the constant and the trend components of the model; whereas the 
trend is of importance in the long term forecasting, the seasonal component is very important in short term forecasting as it is the main source of short run fluctuations.. In this study, all model variables are seasonally adjusted before estimation in VAR was made.

\section{Unit Root Test}

Spurious regression problem is common in time series regressions. Hence, setting the right order of integration of each time series data has to be made before VAR regression. The unit root test helps to set the order of selection, hence to detect and avoid spurious regression problem. To that end, the order of integration of each time series variable was made.

There are different Unit Root Test criteria. The most widely used selection criteria is Augmented Dickey-Fuller (ADF) test. Summary of Unit Root Test for model variables is depicted under table below

Table 2: Summary of Unit Root Test for Model Variables

\begin{tabular}{|c|c|c|c|c|c|c|}
\hline$\overline{\text { S/No }}$ & Variable & $\begin{array}{l}\text { Variable (Seasonally } \\
\text { Adjusted and Log } \\
\text { Transformed) } \\
\end{array}$ & ADF, I(1) & $\begin{array}{c}1 \% \\
\text { (Critical Values) }\end{array}$ & $\begin{array}{c}5 \% \\
\text { (Critical Values) }\end{array}$ & $\begin{array}{l}10 \% \\
\text { (Critical } \\
\text { Values) } \\
\end{array}$ \\
\hline 1 & Import & LNIMPORT* $^{*}$ & -7.973821 & -3.5889 & -2.9303 & -2.6030 \\
\hline 2 & Export & LNEXPORT $^{* *}$ & -7.530118 & -3.5930 & -2.9320 & -2.6039 \\
\hline 3 & Food Price Index & LNCPIF* & -3.634257 & -3.5889 & -2.9303 & -2.6030 \\
\hline 4 & Communication Price Index & LNCOMMUNICATION* & --6.224109 & -3.5889 & -2.9303 & -2.6030 \\
\hline 5 & Education Price Index & LNEDUCATION* & -3.617568 & -3.5889 & -2.9303 & -2.6030 \\
\hline 6 & Employment & LNEMPLOYG* & -6.375550 & -3.5889 & -2.9303 & -2.6030 \\
\hline 7 & Government Expenditure & LNGOVTEXPEND* & -4.967246 & -3.5889 & -2.9303 & -2.6030 \\
\hline 8 & Health Price Index & LNHEALTH* $*$ & -5.328321 & -3.5889 & -2.9303 & -2.6030 \\
\hline 9 & Transport Price Index & LNTRANSPORT** & -4.741770 & -3.5889 & -2.9303 & -2.6030 \\
\hline 10 & $\begin{array}{l}\text { Hotel \& Restaurant Price } \\
\text { Index }\end{array}$ & LNHOTELREST*** & -5.839783 & -3.5930 & -2.9320 & -2.6039 \\
\hline 11 & Investment & LNINVST* & -5.396353 & -3.5889 & -2.9303 & -2.6030 \\
\hline 12 & $\begin{array}{l}\text { World Pandemic Uncertainty } \\
\text { Index }\end{array}$ & WPUI*** & -2.701929 & -3.5850 & -2.9286 & -2.6021 \\
\hline
\end{tabular}


The ADF test shows that the order of integration for all model variables except World Pandemic Uncertainty Index (WPUI) is one i.e. I (1). The result on ADF Test shows that all variables qualifies for regression at order one I(1); and the WPUI qualifies at level i.e. I (0).

\section{Ordering of Model Variables}

A Cholesky decomposition requires the variables to be ordered in a particular fashion, where variables placed higher in the ordering have contemporaneous impact on the variables which are lower in the ordering, but the variables lower in the ordering do not have contemporaneous impact on the variables those are higher in the ordering.

In essence, ordering of variables in VAR model estimation dictated by theoretical and/or empirical evidences on the subject of analysis. Contextual factors are also key aspect of ordering of model variables. In this study, both theoretical/empirical and contextual factors pertaining the COVID-19 shock and particular feature of Ethiopian economy were integrated to conceptualize the ordering of model variables.

As a matter of fact, COVID-19 uncertainty shook is an exogenous variable, and its effect on the economy, at least in the short run, is interpreted in its effect on macroeconomic stability. In essence, COVID-19 shock direct and immediate effect on the economy is via distorting the supply chain. Supply chain distortion effect in return spills over in to the domestic economy by distorting import sector. Distortions in import quickly transmitted into the economy by affecting transport/logistics sectors. As Ethiopian domestic supply chain is largely dependent on importable for consumption and investment goods, COVID-19 impact on macroeconomic stability of Ethiopia is felt at the earliest via import and transport/logistics shocks.

The effect of the pandemic via supply chain shocks is quickly transmitted into disturbing the aggregate demand.

As such, both aspects of aggregate demand i.e. consumption and investment demands (expenditures) affected by supply chain distortions. In this regard, while prices on basic consumption items (like food and medical/pharmaceuticals) are expected to sky rocketed as people rush to hold for uncertain future. On the other hand, demand for investment goods is 
expected to decline, whose effect would be in dwindling down prices on investment goods. Supply chain distortions also have upward pressures on the cost of doing businesses by soaring key inputs (soft and hard inputs) in investment undertakings. While supply chain shock effect is translated into demand side shocks via consumption $\&$ investment expenditures price volatilities is expected in the process. As Ethiopian investment sector is growing to be export oriented, the effect of the pandemic on investment is quickly translated into affecting export earnings (performance of export sector).

The combined effects of supply chain and demand distortions takes its toll into the economy by affecting real variables mainly the employment creation capacity of the economy.

To mitigate the COVID-19 pandemic shock effect on the pillars of the economy, government interventions in the economy is expected to grow. Indeed, one of the legacies of COVID-19, as depicted in many studies so far, is reminding for the crucial role of government sector. In Ethiopian context too, as depicted in COVID-19 recovery package, the government is set to intervene to mitigate the effect of virus by indulging in massive fiscal stimulus plan.

In lieu of the illustrations made in the previous paragraphs, the order of variables in the VAR estimation in this study assumes the following:

WPUI $\Rightarrow$ IMPORT $\Rightarrow$ TRANSPORT $\Rightarrow$ FOOD \& NON-FOOD PRICES $\Rightarrow$ INVESTMENT $\Rightarrow$ EXPORT EMPLOYMENT $\rightarrow$ GOVERNMENT EXPENDITURE (FISCAL POLICY)

\section{Predicting COVID-19 Shock Impact Using BVAR Model: Impulse Response Function (IRF)}

Impulse response functions can be used to produce the time path of the dependent variables in the VAR, to shocks from all the explanatory variables. If the system of equations is stable any shock should decline to zero, an unstable system would produce an explosive time path.

In this study, COVID-19 uncertainty shock impact is estimated instrumenting World Pandemic Uncertainty Index on Ethiopia (WPUI) over macroeconomic indicators integrated in BVAR model. Hence, the Impulse Response Function (IRF) is generated from BVAR estimation. The result on Impulse Response Function (IRF) of each endogenous variables of the model in response to one standard deviations of WPUI is presented in graphs. 
The span of prediction period is set to be 14 quarters or Three years and two months since January 2020 (or MEGABIT, 2012 E.C)

\section{The COVID-19 Shock Transmission Mechanism into the Economy Using BVAR}

To depict on the transmission mechanism of the pandemic uncertainty shock, the BVAR Variance Decomposition was estimated. Variance Decomposition is an alternative method to the impulse response functions for examining the effects of shocks to the dependent variables. This technique determines how much of the forecast error variance for any variable in a system, is explained by innovations to each explanatory variable, over a series of time horizons. Usually own series shocks explain most of the error variance, although the shock will also affect other variables in the system.

In this study, the result of Variance Decomposition on each endogenous variables of the model in response to one standard deviations of WPUI is made is presented in tables.

\section{Investigating the Role of Fiscal Policy for Macroeconomic Stability}

In this study, the role of fiscal policy to mitigate COVID-19 driven macroeconomic instability on Ethiopian economy is examined by instrumenting fiscal policy shocks against key macroeconomic variables integrated in VAR model used. Expansionary fiscal policy instruments examined in this study are increasing government expenditure and reducing import tariffs. By way of illustration, impulse response of key macroeconomic stability indicators to COVID-19 shock (the disturbance factor) and the expansionary fiscal policy shocks (counter disturbance factors) is presented. 


\section{RESULTS AND DISCUSSION}

For over a decade, Ethiopian economy has been on a rise, with average growth rate $10.1 \%$ between 2003 and 2019, the country`s economy is still unable to put structural transformation that would withstand shocks attributed to natural and non-natural shocks. Rain fed agriculture is the major pillar of the economy in terms of employment, foreign trade and domestic supply chain.

It is amidst those prevailing real economic shocks that the country is faced with another more turbulent shock, this time COVID-19 pandemic shock. The effect of COVID-19 to Ethiopia further adds up to the woes of the mentioned structural problem and susceptibility of the shock.

But how deep would the COVID-19 pandemic be in the short run period? How would COVID19 shock impact the Ethiopian economy? Where is the transmission mechanism of the economic pandemic? This chapter tries to address on those and related topics. 
The finding of the study reveals that the COVID-19 impact lasts at least three years to shake the economy of Ethiopia.

Essentially the COVID-19 immediate impact is on international transactions of the country, hence the supply chain distortions. As Ethiopia relies heavily on import to supply on basic items for consumption and investment demands, the immediate damage effect of COVID-19 would be distorting supply chain. The study result reveals that pandemic Shock on supply chain quickly transmitted into aggregate demand, where a slum in aggregate demand expected to prevail at least in the coming three years since 2020.

\subsection{COVID-19 Uncertainty Shock Effect on Import Demand in Ethiopia (2013-2015 E.C)}

The VAR estimate indicates that COVID-19 uncertainty shock results a massive rise in import in the second half of 2019/20 Ethiopian Fiscal Year (E.F.Y) or (2019/20 Q3 and Q4). In the period between months of January-June 2020 (TIR-SENE 2012 E.C), import demand is expected to grow by 4.17 billion birr. The finding in this regard is expected, as the pandemic triggers massive demand in food and pharmaceuticals, for which Ethiopia is import dependent on both items.

The magnitude \& direction of COVID-19 shock effect on import demand in the last two quarters of 2019/20 E.F.Y is not the same. In the months from TIR-MEGABIT 2012 E.C. (i.e. the third quarter of 2019/20 E.F.Y) import demand will decline by 1.71 billion birr. This reduction is expectedly due to immediate restrictive measures taken by countries worldwide (including countries where Ethiopia depends for its imports) after World Health Organization declared COVID-19 outbreak a Public Health Emergency of International Concern on 30 January 2020.

However, the decline in import in the period TIR-MEGABIT 2012 E.C is expected to be offsettled by a massive increase in the next quarter i.e. MIAZIA-SENE 2020 E.C), where forecast estimate puts an increase of import demand by 5.89 billion birr in this period.

This overwhelming in import demand between the months of MIAZIA- SENE/ 2012 E.C may be attributed to two interrelated factors: the momentum effect and the inelasticity nature of Ethiopian import items. 


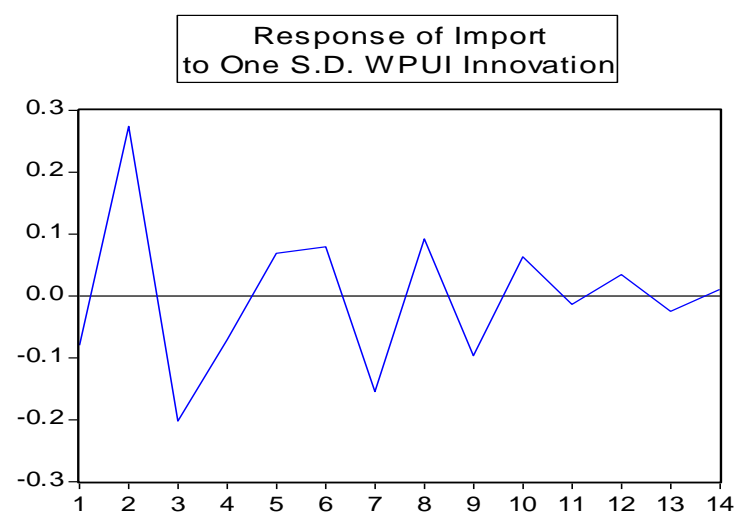

Figure 2: Dynamic Response of Import to COVID-Uncertainty Shock

The momentum effect captures the pressure of a reduction of import in the first quarter puts on import in the second quarter. COVID-19 triggered major import partner countries of Ethiopia to remain in shut down for over three months so. And a halt in import in the first quarter is expected to have momentum effect on the second quarter. On top of that, Ethiopia is net importer on two basic commodities required to deal with coronavirus pandemic days: pharmaceuticals and food items. That explains why import shows a rise in the second quarter of forecast period.

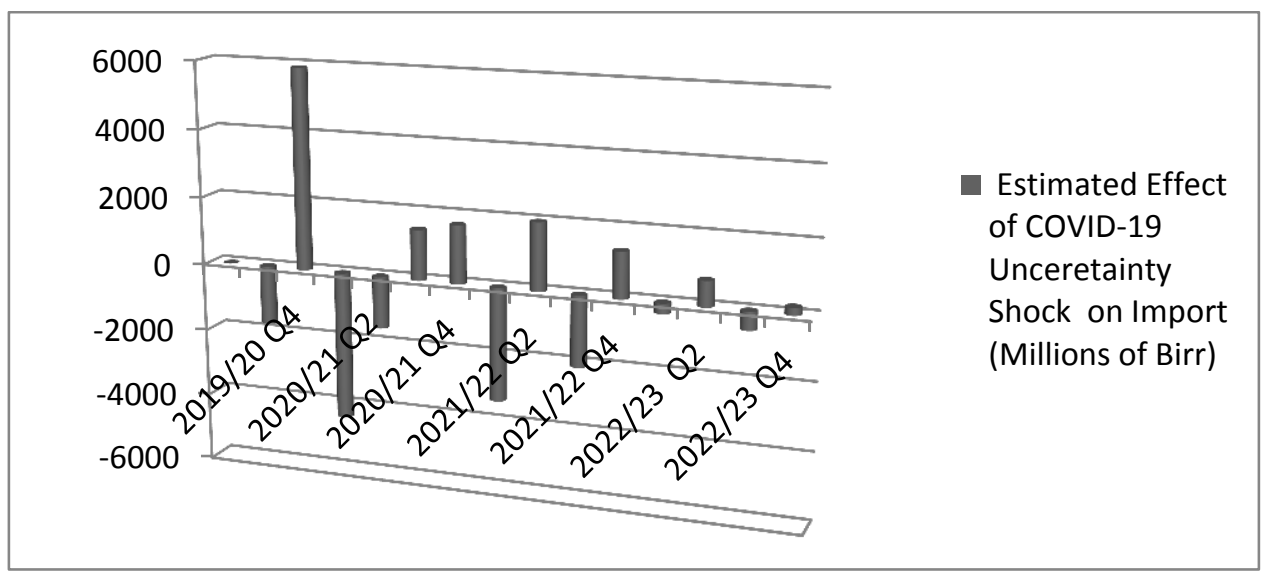

Figure 3: Estimated Effect of COVID-19 Uncertainty Shock on Import (Millions of Birr)

(Author`s Computation based on VAR Forecast via Impulse Response Function)

In the year 2013 E.C, as a result of COVID-19 uncertainty effect, import declines by 2.68 billion birr. Decline in import continues in 2014 E.C too, with an estimated decline in import values by 2.06 billion birr. A decline in imports in the successive years (2013-2014 E.C) is explained by 
expected decline in consumption \& investment expenditures, which are highly import dependent in the Ethiopian context, as result of the virus effect.

However, the decline in import ceases in 2015, where the pandemic uncertainty effect results an increase in import by 133 million. This marks s recovery of the economic recovery from COVID-19 tolls.

However, the decline in import ceases in 2015, where the pandemic uncertainty effect results an increase in import by 133 million. That perhaps signals recovery of Ethiopian economy from COVID-19 tolls.

COVID-19 Uncertainty Shock Transmission Mechanism on Import Volatility (2013-2015 E.C)

In the first four quarters ahead, the impact of COVID-19 uncertainty shock on import is transmitted to the economy via food prices. A rise in food prices in the immediate aftermaths of the pandemic is expected as Ethiopia is net importer of food and food supplements.

Since the fifth quarter of forecast period, COVID-19 triggered import volatility is much explained by volatilities in non-food prices. In this regard, education, hotel \& restaurant and transport sectors would be the major channels through which the uncertainty shock transmitted into the economy. 


\subsection{Forecasting COVID-19 Uncertainty Shock Effect on Export Earnings (2013-2015)}

The uncertainty impact of COVID-19 on export is another focus of inquiry of this study. The dynamic time path of forecast effect of COVID-19 on export earnings of Ethiopia is depicted in Impulse Response Graph below.

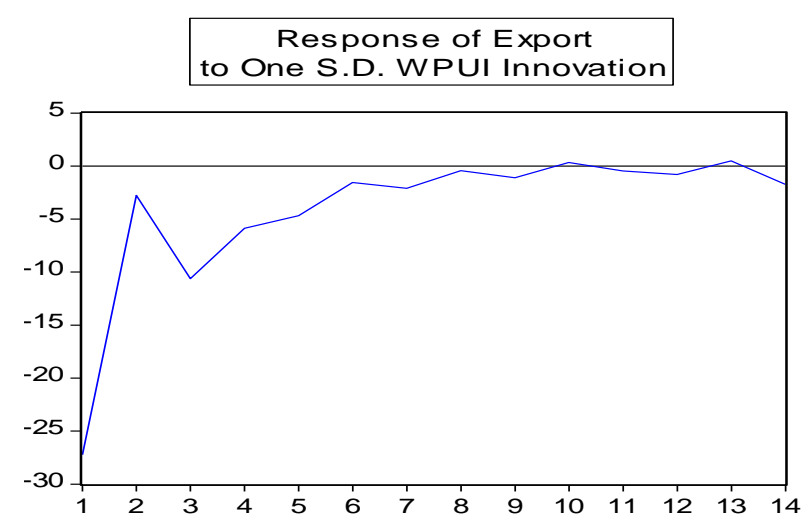

Figure 4: Dynamic Response of Export Earnings to COVID-Uncertainty Shock

As we learn from IRF graph, export thoroughly declines in all forecast periods. The loss in export earning is massive three months starting TIR- MEGABIT 2012 E.C, where export earnings declines by 5.85 Billion birr.

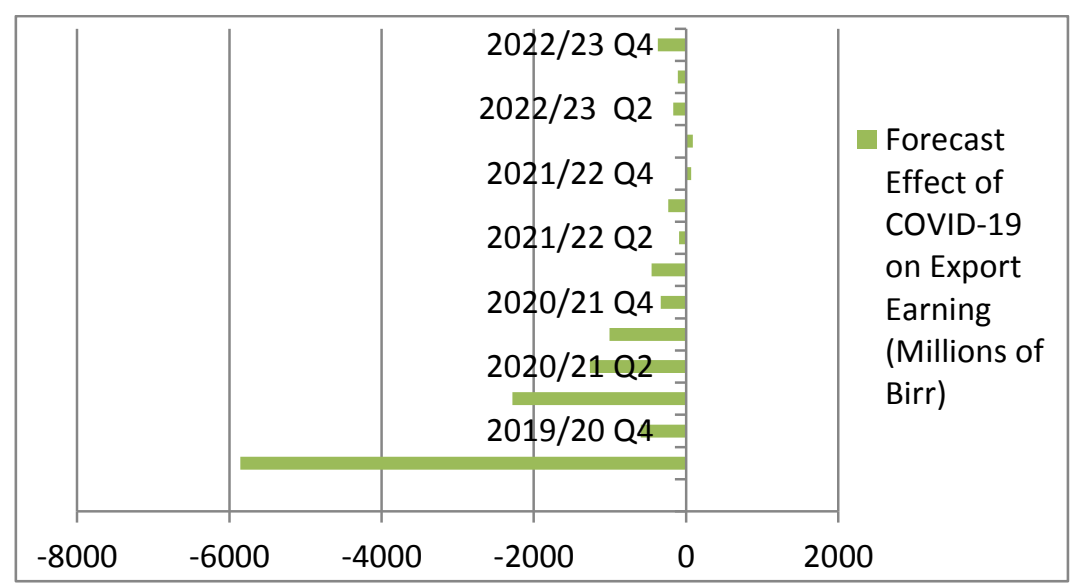

Figure 5: Forecast Effect of COVID-19 on Export Earning (Millions of Birr)

(Author`s Computation based on VAR Forecast via Impulse Response Function)

In the first six months since January 2020 (TIR/2012), an estimated 6.5 billion birr will be lost as a result of COVID-19 uncertainty shock effect. The study forecasts export to decline by 597.7 
million birr April-June 2020 (MIAZIA-SENE 2012 E.C). This finding fits (only with forecast error of 3.5\%) the forecast estimate made by Ministry of Finance of Ethiopia in April 2020,. According to Ministry of Finance of Ethiopia, export earnings are expected to fall by 30\% (576 million birr) between March and June 2020 compared to earnings from exports in the same period in 2019 (which was 19.2 billion birr) (FDRE Ministry of Finance, 2020)

The decline in export keeps between July and September 2020 (HAMLE 2012-MESKEREM 2013 E.C).

In the year 2013, export loss due to COVID-19 shock is estimated to reach 4.8 billion birrs. The total loss in export in the first six months of 2013 E.C will be 3.5 billion birr. In next half year following, the predicted loss in export earnings in estimated at 1.34 billion birr. The impact of the pandemic on export earnings of Ethiopia shows a progressive decline in 2014 E.C. The total loss as a result of pandemic shock effect in 2014 E.C. is forecasted to reach 709.71 million birr. In the year 2015, the damage cost of COVID-19 on export earnings of Ethiopia is estimated at 557 million birr.

The pandemic uncertainty effect on export, though shows a steep decline, remains to be felt up until 2017 E.C.

\subsubsection{COVID-19 Uncertainty Shock Transmission Mechanism on Export Expenditure Volatility (2013-2015 E.C)}

The pandemic effect on export earnings of Ethiopia, at least in the coming three years, is largely explained by the duration of the pandemic period itself. As such, pandemic shock explains an average of $65.66 \%$ of variation (decline) in export earnings. A result from variance decomposition result also reveals that transport and investment shocks another mechanisms COVID-19 uncertainty effect transmitted into the export sector between the years 2012-2015 E.C. 


\subsection{Forecasting COVID-19 Uncertainty Shock Effect on Investment Expenditure}

One of the impacts of COVID-19 is its toll in downsizing key components of aggregate demand, consumption and investment expenditures. In uncertain times like our days, both households and firms prefer to withhold their cash. Households would set aside cash in their hands for food and basic amenities. Firms too, refrain from spending to build-up their capital stock. Overall, both consumption and investment demands are expected to slump in the pandemic period.

In this study, the impacts of COVID-19 on the aggregate demand in Ethiopian economy is investigated through the pandemic's effect on investment expenditure, one component of The study found out that COVID-19 driven investment volatility lasts three years. To examine on investment expenditure dynamics between TIR/2012 and SENE 2015, changes to Investment expenditure to one standard deviation of World Pandemic Uncertainty Index is generated using VAR Impulse Response Function (IRF).

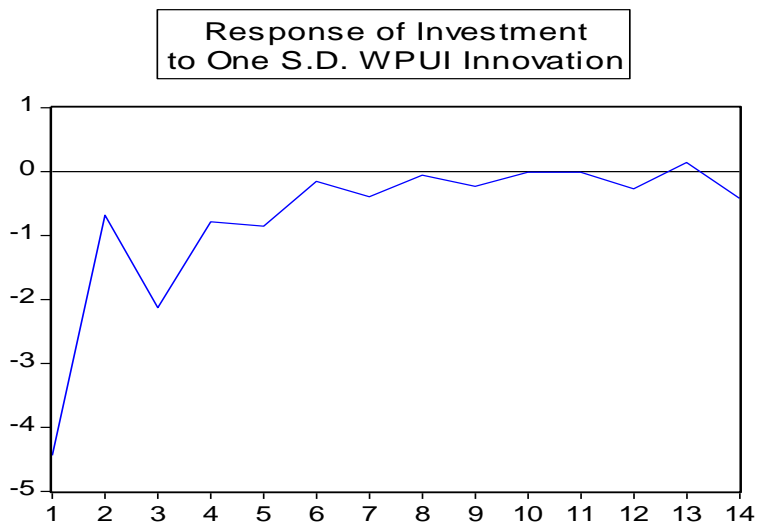

Figure 6: Dynamic Response of Employment to COVID-Uncertainty Shock

According to forecast estimate made, the total damage on investment expenditures from TIR 2012- SENE 2015 will be 1.9 billion birr (63.95 Million USD). The finding further reveals that, in the coming three years at least, investment performance is largely determined by the length of the pandemic period (pandemic uncertainty effect), explaining on average 56\% of loss in investment expenditure. The result is in compatible with investment theories and empirics, where uncertainty what so ever is the major shock variable affecting investment. Next to pandemic uncertainty factor, transport and export sectors are also the major shock variables in 2012-2014 
E.C. In 2015, investment is largely affected by hotel \& restaurant prices and government expenditure shocks.

The size of investment expenditure losses and the dynamic impacts of major determinants of investment performances vary across different quarters/years in the prediction period (in the next three years). Investment expenditure steeply declines in the upcoming two years since TIR 2013. The biggest loss forecasted to hold between months of January (TIR) and (MEGABIT) 2012 E.C., where an estimated 443.82 million birr worth of investment expenditure decline is expected.

Overall, in the six months of 2012 E.C, COIVID-19 pandemic uncertainty shock results half a billion birr (512 Million birr). In this period, investment decline is largely attributed to Pandemic uncertainty shock $(82.83 \%)$. Other than pandemic uncertainty, transport and export shocks takes a respective shares of $9.9 \%$ and $6.49 \%$ for a decline in investment in the period between TIR and NEHASE 2012.

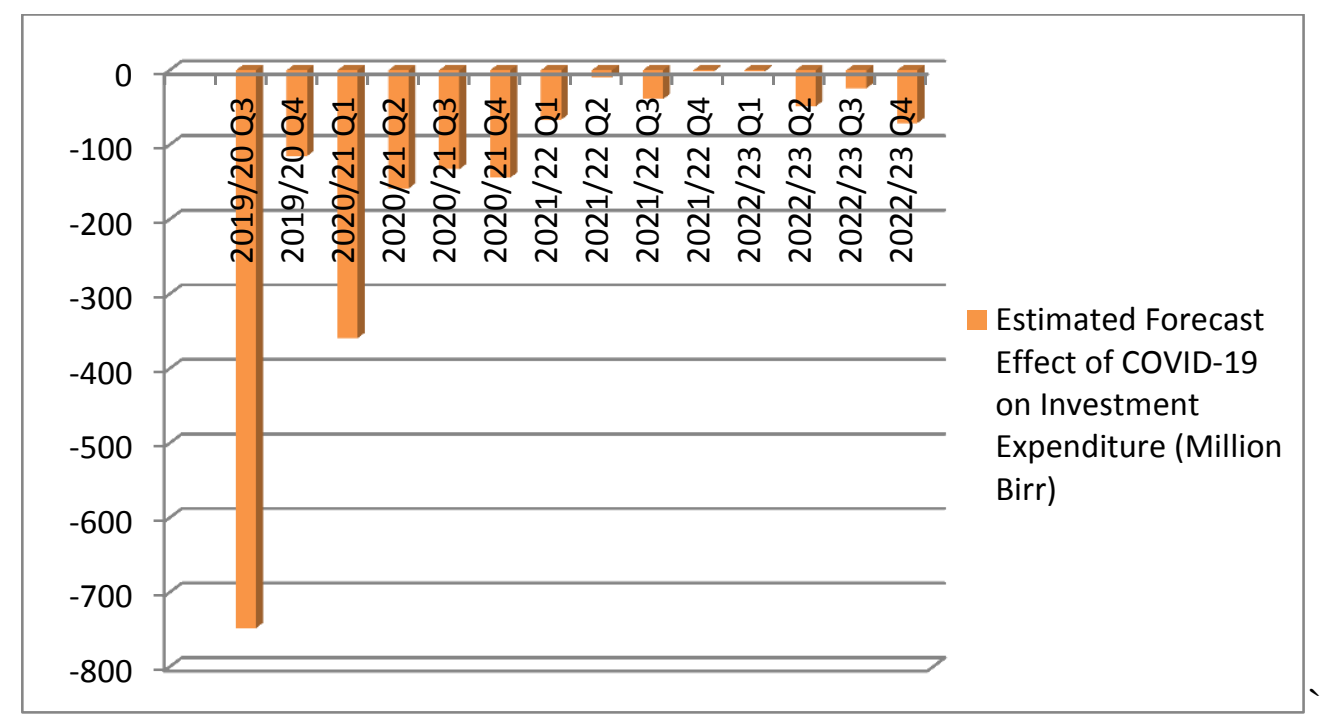

Figure 7: Forecast Estimate of Effect of COVID-19 Pandemic Uncertainty on Investment Expenditure in the Three years

(Author`s Computation based on VAR Forecast via Impulse Response Function) 
In 2013 E.C too, the effect of the virus keeps on its damage on investment climate in Ethiopia. In this regard, the total cost of pandemic uncertainty is estimated to be 391.77 million birr. Though the pandemic uncertainty shock effect shows a progressive decline, it still remains the major factor determining the performance of investment sector in 2013, contributing on average for $62.32 \%$ of investment volatility. In the mentioned period, transport and export shocks remain on top spot of affecting investment performance, with respective the average shares in explaining investment expenditure is predicted to be $8.39 \%$ and $4.87 \%$.

The effect of the pandemic on investment shows a relative decline in 2014 E.C, whose estimated effect on loss in the investment expenditure predicted at 68.7 Million birr. This is largely attributed to a decline in pandemic uncertainty shock, whose effect declines to $49.12 \%$. Transport prices and export shocks remain major variables in 2014 where COVID-19 uncertainty shock effect takes its toll on investment performance in Ethiopia. The finding from VAR estimation shows transport price shocks are forecasted to explain $8.63 \%$ of volatilities in investment expenditure. In 2013 E.C the role of export performance in explaining investment volatilities is averaged at $4.12 \%$.

In the year 2015 E.C, the damage of the pandemic on investment expenditure will be and 84.2 Million birr respectively. In this period, the relative importance of pandemic uncertainty, transport and export shocks progressively declines in affecting investment expenditures. In this regard, the share of each shock in affecting investment stability is predicted to be $43.1 \%, 7.96 \%$ and $3.79 \%$ respectively. On the other hand, the importance of hotel \& restaurant and government expenditure shocks appeared on the scene to shake investment sector. The Impulse

Response results from VAR estimation predicts that hotel \& restaurant prices \& government spending explain on average $7.14 \%$ and $6.01 \%$ of changes in investment expenditures respectively.

\subsection{Forecasting COVID-19 Uncertainty Shock Effect on Price Stability (2013-2015 E.C)}

The impact of COVID-19 on macroeconomic stability can be gauged by its effect on price volatility. Theoretical and empirical evidences tell price stability a signal about the health of the economy. For one, it can be rough gauge on the gap between the aggregate demand and supply. Moreover, price volatilities also implicate the shock level in the economy. The importance of 
looking the impact of COVID-19 is key from the two broader aspects of linkages between macroeconomic stability and price volatility.

\subsubsection{Forecasting the Effect of COVID-9 on Food Prices}

The VAR model result predicts that COVID-19 pandemic shock to have an upward pressure on food price index ${ }^{6}$. As shown from IRF graph below, food prices are predicted to show a rise in most of the forecast Two explanation can be given why food prices surge in the pandemic period. One, health preventive measures would give food market disruptions mainly creating transport \& logistics service barriers, among other factors. Two, the pandemic uncertainty effect would raise households` precautionary demand for food, whose effects interpreted in pushing food prices up..

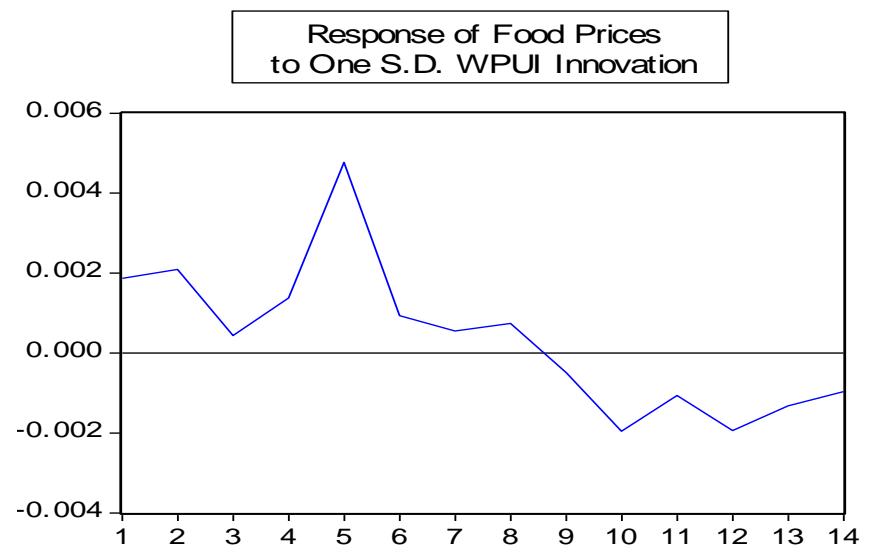

Figure 8: Dynamic Response of Food Prices to COVID-Uncertainty Shock

To infer on the channels through which food price volatility to be transmitted into the economy, variance decomposition of food prices shock was made. Accordingly, transport shock is forecasted to be the main channel through which COVID-19 uncertainty effect is impact is transmitted into food prices. On average $16.3 \%$ of variances in price of food-price is explained by transport prices in the whole periods of forecast. As food inputs are highly reliant on transport $\&$ logistics services, it is natural that food prices to vary with transport prices.

Education price is another channel where COVID-19 uncertainty shock impact is transmitted to food price volatility in Ethiopia in the upcoming three years, whose shock effect on food price

\footnotetext{
${ }^{6}$ The basket of goods/services in the estimation on food price index in Ethiopia involves the following items: bread and Cereals; Meat; Fish \& Sea Food; Milk, Cheese \& Egg; Oils \& Fats; Fruits; Vegetables; Sugar, Jam, Honey, Chocolate \& Confectionery; Food Products; Non-Alcoholic Beverages.
} 
volatility is averaged at $14.9 \%$ in the prediction period. In a country like Ethiopia, where there are 26 million students attending classes as of 2020 or 2012 E.C ${ }^{7}$, it is highly likely that education sector to affect food prices via effects on hotel \& restaurant businesses. Indeed, a stay at home health measures affect hotels and restaurants drawing substantial customer base from getting services. That inevitably put downward pressure on food prices through the line of demand shortfalls. That may explain why the impact of education prices is expected to spill over into food prices.

Apart from education, the impact of COVID-19 on food prices are expected to pass through communication prices, particularly since the first four quarters of prediction period.

\subsubsection{Forecasting the Effect of COVID-19 on Non-Food Prices ${ }^{8}$}

To see the dynamic response of non-food prices to COVID-19 uncertainty shock, the study consider major items in non-food price indexing in Ethiopia. Hence, the dynamic response of indicators of non-food price index to one standard deviation of COVID-19 uncertainty shock on transport, communication, education, health and hotel \& restaurant prices is forecasted for the next fourteen quarters since 2019/20 Q3

As depicted in subsequent paragraphs, the forecast result reveals that the pandemic uncertainty impact is not the same across non-food goods/services indicators.

\section{Transport Prices}

In the immediate aftermath of the pandemic outbreak, transport prices show upsurge, but only with a momentous effect as it lasts for few time. This can be explained by pressure on public mobility on the eve of stay at home measures likely be implemented on the wake of the coronavirus pandemic. People would rush at once to take themselves at home, raising transport demand and hence surge in the price index. Moreover, the future is uncertain with more restrictive measures (including lockdowns) may hold. Therefore, precautionary demands for food

\footnotetext{
${ }^{7}$ Report by Planning Commission of Ethiopia, July 2020

${ }^{8}$ In Ethiopian context, non-food price index is computed on average price index for the following list of products: Transport, Communication, Education, Health, Hotel \& Restaurant, recreation \& culture; Alcoholic Beverages and Tobacco; Clothing \& Foot-wear; Housing, Water, Electricity/Gas and Other Fuels; Furnishings, Household Equipment and Routine Maintenance of the House; Miscellaneous Goods
} 
/ non-food items, which raise demand for transport services, leaving an upward pressure on transport prices.

Except for a momentous increase in prices of transport, the VAR model forecast transport prices fall in almost all quarters of forecast period. Given the pandemic triggered stay away measures, that would amount significant limitations on mobility of people and freight, all with dwindling down effect on transport prices. The impact of COVID-19 uncertainty shock on transport prices seemingly fades beginning $12^{\text {th }}$ quarter of forecast.

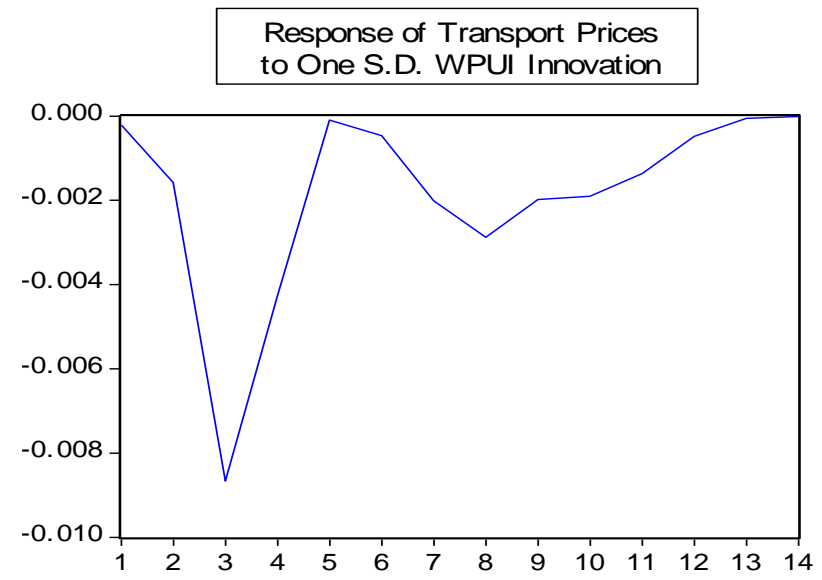

Figure 9: Dynamic Response of Transport Prices to COVID-Uncertainty Shock

Moreover, the pandemic uncertainty shock is transmitted to transport price volatility via education and food prices, also with investment. The result in this regard is expected as education, food supply chain and investment activities are highly reliant on transport services.

\section{Communication Prices}

Communication prices show a rise in the upcoming six quarters at least. The rise in price is also observed in the seventh and eighth quarters too before falling in the last two quarters of forecast.

The upward effect of COVID-19 pandemic on communication price index is understandable. For obvious reasons, the pandemic preventive measures required limited physical contact. and the only feasible way managing one's business, whether economic or social, would be via telecommunications. That in turn results into surge in demand for communication devices/services, hence a rise in their prices too. 


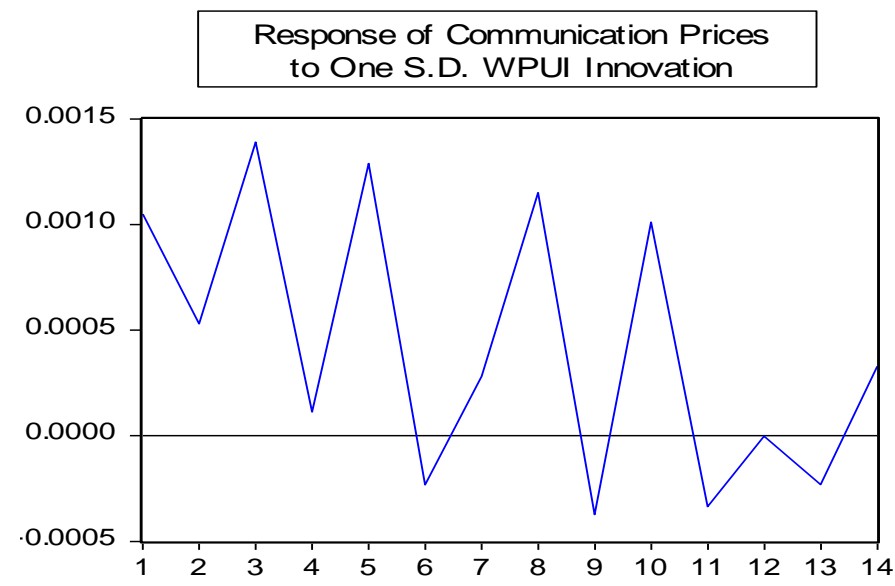

Figure 10: Dynamic Response of Communication Prices to COVID-Uncertainty Shock

Volatilities in communication prices are predicted to be explained via volatilities in prices in the health and food prices. Export sector is another channel where COVID-19 uncertainty shock evokes volatilities in the communication prices. The finding is consistent with the fact that all those sectors are largely dependent on communication devices to deliver/function their services.

\section{Education Prices}

Education prices show a fall in the next three forecast period, but begins a steady rise that lasts for the next five quarters. The finding is in compatible with the stringent measures to be taken in the aftermath of the pandemic, one of which is closure of education centers.

As education remains in closure for months, demand for education services and education materials would be low. And the impact is interpreted with a fall in education prices. That explains why education price index shows a decline in the months following COVID-19 pandemic. 


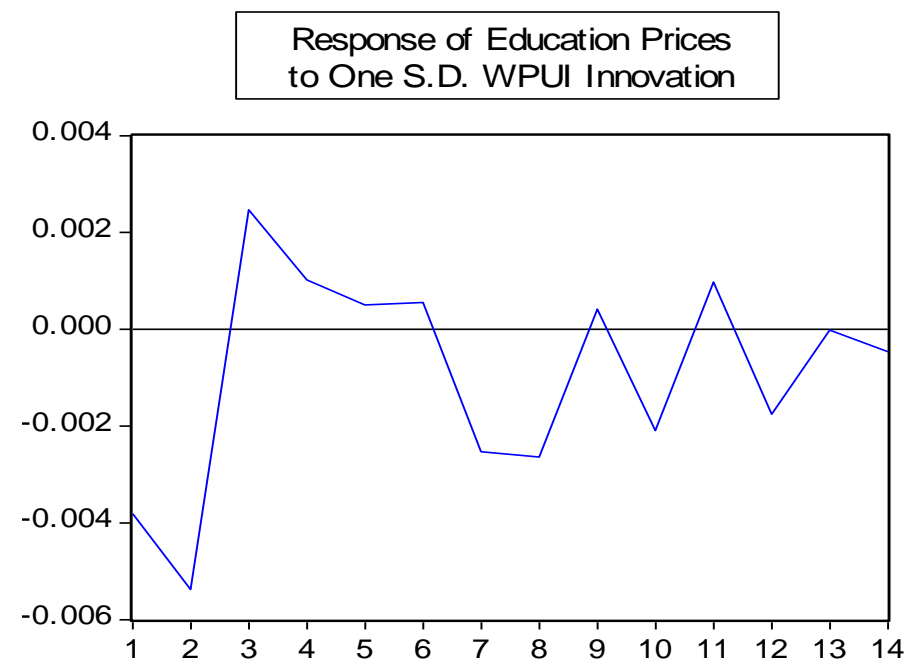

Figure 11: Dynamic Response of Education Prices to COVID-Uncertainty Shock

As forecasted in the VAR variance decomposition, the transmission channel of the pandemic effect on education sector is most felt through transport and food price shocks. The duration of pandemic uncertainty time is also another factor affecting the stability of education prices in the next couple of years in Ethiopia. Since the beginning of the fourth quarter of forecast, communication price shocks will affect stability of education prices.

\section{Health Price Index}

Health prices show a rise in the first two quarters of forecast. Given the pandemic result a public health measures to step up, the prediction is as expected. However, for the next three quarters, health prices show a decline. The impact of COVID-19 uncertainty shock on health prices culminates beginning the seventh quarter.

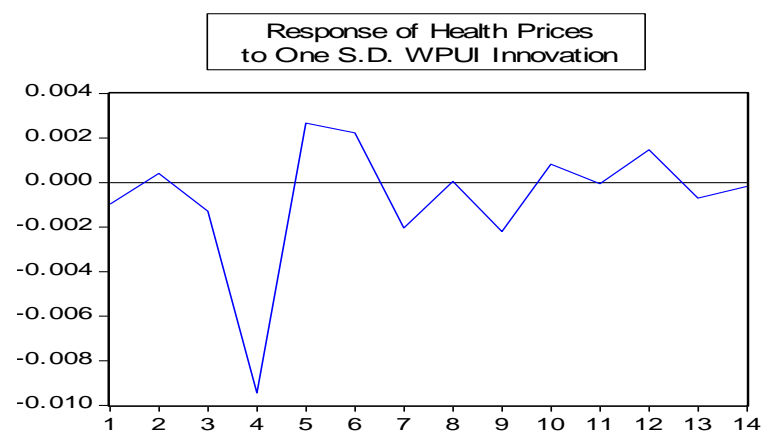

Figure 12: Dynamic Response of Health Prices to COVID-Uncertainty Shock 
The transmission channel of uncertainty effect on health price stability is most explained by communication, transport \& food price shocks. Import and hotel \& restaurant prices are also found to be another transmission mechanism of COVID-19 uncertainty shock on variations in health price in the forecast period.

\section{Hotel \& Restaurant Prices}

Hotel \& restaurant prices increase roughly in all periods of forecast except the fourth and fifth quarters. Given that public health measures required hotels \& restaurant business to put in place changes in their service delivery to complying customer safety that inevitably interpreted in making cost of production costlier. The in part explains the upward pressures on hotel \& restaurant prices expected in the first four quarters at least.

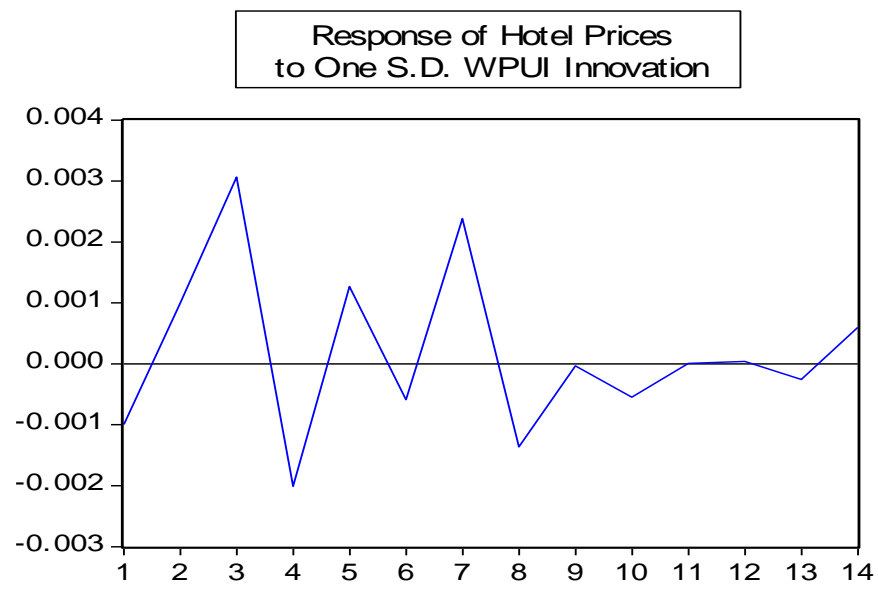

Figure 13: Dynamic Response of Hotel \& Restaurant Prices to COVID-Uncertainty Shock

The impact of COVID-19 pandemic takes its biggest toll in the hotel \& restaurant business via education and food price volatilities. As food items are major inputs/outputs of hoteling business, and students are the major customers of hotel \& restaurant services, the finding is expected. Nonfood prices like communication and transport are also important lines of uncertainty shock transmission lines resulting volatilities in the hotel \& restaurant prices. 


\subsection{Forecasting COVID-19 Uncertainty Shock Effect on the Pattern of Public Expenditure in Ethiopia (2013-2015 E.C)}

The pandemic shock effect has a negative impact on government expenditure in the next four quarters of pandemic period. As the forecast estimation considers policy factors intact, one reason why reduction of public spending is because a reduction in government earnings due to tax and tariff falls as result of the pandemic.

An increase in government expenditure is forecasted in the first quarter of prediction period. Government spending shows a decline in the last quarter of 2019/20 fiscal year and the first quarter of 2020/21 fiscal year. In the remaining three quarters of the 2020/21 fiscal year, however, a slight increase in government expenditure is expected. The pattern of government expenditure change appears to be cyclical in the next quarters of forecast.

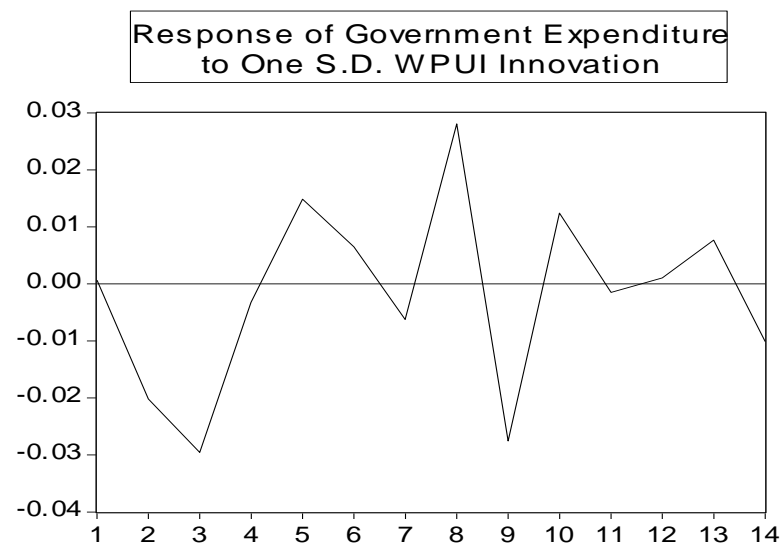

Figure 14: Dynamic Response of Government Expenditure to COVID-Uncertainty Shock

\subsubsection{COVID-19 Uncertainty Shock Transmission Mechanism on Public Expenditure (2013- 2015 E.C)}

To see the effect COVID-19 uncertainty shock on macroeconomic stability in Ethiopia, the study examined the transmission mechanism of Government Expenditure volatility. To that end, variance decomposition on government expenditure variable is estimated in the VAR model.

The result of estimation shows that volatilities in government expenditure transmitted into the economy by affecting prices, both food and non-food prices. In this regard, food and 
communication prices appear to be main channels through which COVID-19 shock transmitted into government expenditure volatility.

As variance decomposition result shows, communication prices shocks are the main transmission channel of COVID-19 uncertainty shock on government expenditure, explaining $15.74 \%$ of public expenditure volatilities in the forecast period (the coming three years). The explanation goes to structural/contextual factor pertaining to the public sector in Ethiopia. The role of communication sector in determining the pattern of government expenditure is apparent as direct and indirect source of government revenues.

In Ethiopian context, communication sector is entirely owned by the government sector, with the state monopolizes the telecom business to fetch ransom to service its expenditure. Moreover, the effect of communication shock on government expenditure may be through its potential impact on the tax revenue.

The study further identified that COVID-19 uncertainty effect is transmitted into government expenditure via hotel \& restaurant shock. This can be explained by two. For one, hotel \& restaurant business is key source of tax revenue for the government. Moreover, as a result of the pandemic takes its biggest toll on hotel \&restaurant businesses, tax revenue from the sector is expected to face a decline in the next couple of years. On top of that, given that the hotel \& restaurant sector is receiving major tax concessions from the government, the downward effect on tax revenue that could have been received from the sector. 


\subsection{Forecasting COVID-19 Uncertainty Shock Effect on Investment Induced Employment in Ethiopia (2013-2015 E.C)}

As we learn from the dynamic response graph below, uncertainty shock sparked by coronavirus pandemic affect aggregate employment (temporary \& permanent employment) negatively in the first two quarters of forecast period (between TIR and SENE 2012 E.C). Between TIRMEGABIT 2012 E.C), COVID-19 uncertainty shock will result a 65\% decline in employment level compared to the previous quarter (2019/20 Q2).

Dynamics of COVID-19 Uncertainty Shock Effect on Employment in the Forecast period is depicted in the Impulse Response Function (graphed) below

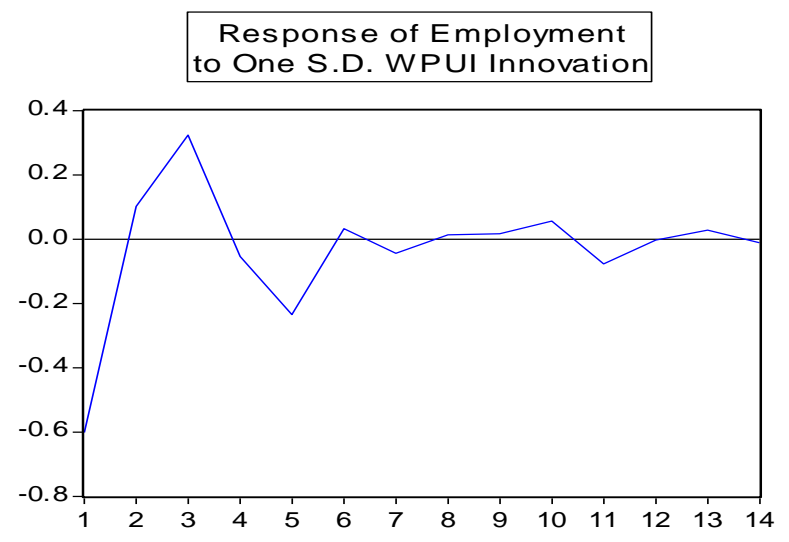

Figure 15: Dynamic Response of Employment to COVID-Uncertainty Shock

The effect of the pandemic on employment is expected to come through investment, the length of the pandemic period (uncertainty effect) and export shocks. The finding is real as the employment data used in the study is investment induced employment; and investment and export sector are largely affected by the length of pandemic period (see sections 4.2 and 4.3 )

Indeed, as VAR forecast estimate show, the impact of COVID-19 uncertainty effect is much felt through investment channels in the whole period of prediction period (three years). In the first six months of 2012 E.C for instance, changes in investment expenditures explain $37.89 \%$ of volatilities in employment. In the first four quarters of forecast period, though permanent employees are not totally immune from the pandemic shocks, temporary employment will bear the cost of the pandemic more than permanent employment. There are solid reason why so. 
For one, COVID-19 triggers stringent public health measures to prevent the spread of the disease restrict the growth of ongoing investments, whose effect interpreted in downsizing additional. Moreover, pandemic uncertainty erodes the confidence of investors as the prospect for businesses expectedly gloomy curbing new investments from holding. In both cases, COVID-19 effect is interpreted in its massive effect on temporary employment.

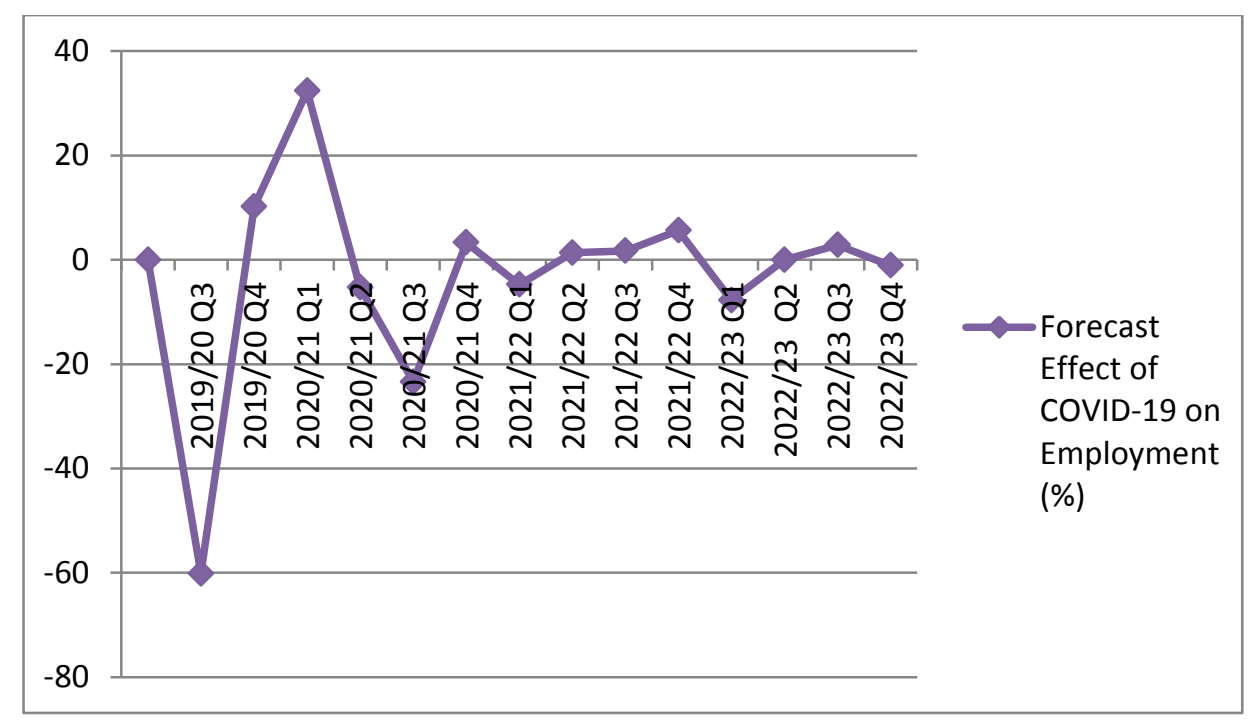

Figure 16: Forecast Effect of COVID-19 on Employment (\%)

(Author`s Computation based on VAR Forecast via Impulse Response Function)

The effect of COVID-19 uncertainty on employment is however almost nil in the year 2014 . This, in part, is explained by a rise in public spending to investment undertakings and existing businesses targeting employees (permanent/contract) from layoffs. As forecast prediction shows, the effect of the pandemic on employment culminates beginning the second half of 2013 E.C 


\subsection{The Role of Fiscal Policy to Mitigate the Uncertainty Shock Impact of COVID-19 Pandemic on Ethiopian Economy (2013-2015 E.C)}

In this study, the role of fiscal policy to mitigate COVID-19 driven macroeconomic instability on Ethiopian economy is examined by instrumenting fiscal policy shocks against key macroeconomic variables integrated in VAR model used. Expansionary fiscal policy instruments examined in this study are increasing government expenditure and reducing import tariffs. By way of illustration, impulse response of key macroeconomic stability indicators to COVID-19 shock (the disturbance factor) and the expansionary fiscal policy shocks (counter disturbance factors) is presented.

\subsubsection{The Role of Managed Rise in Public Expenditure to Stabilize the Economy}

To examine the effect of expanding public expenditure in stabilizing the macroeconomic order, The Impulse Response Function (IRF) to one standard deviation of shock from Government Expenditure on investment, employment, food \& non-food prices, import, export sector was investigated.

Evident from IRF graphs below, the particular role of an increase in government expenditure goes to stabilize general prices (both in the food and non-food prices)
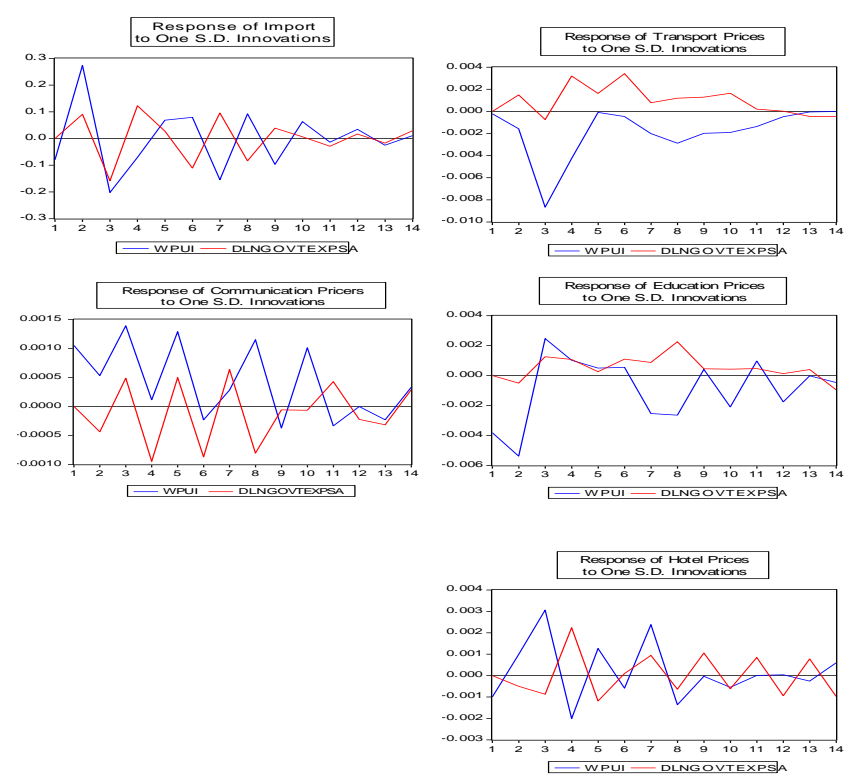

Figure 17: The Role of Expansionary Government Expenditure to Price Stability
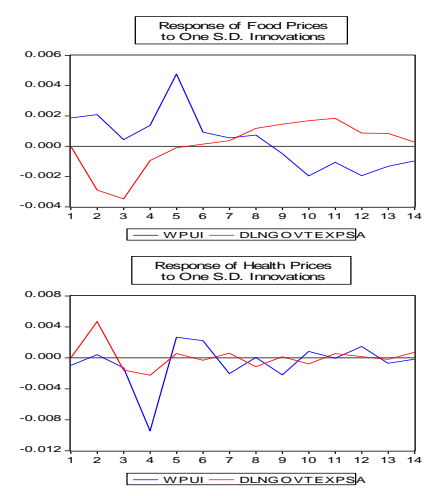

WPUI DLNGOVTEXPSA

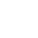


Moreover, increasing government expenditures can heal the fractures of the economy due to pandemic uncertainty shock effect by stimulating investment, export and employment (see IRF graphs below).
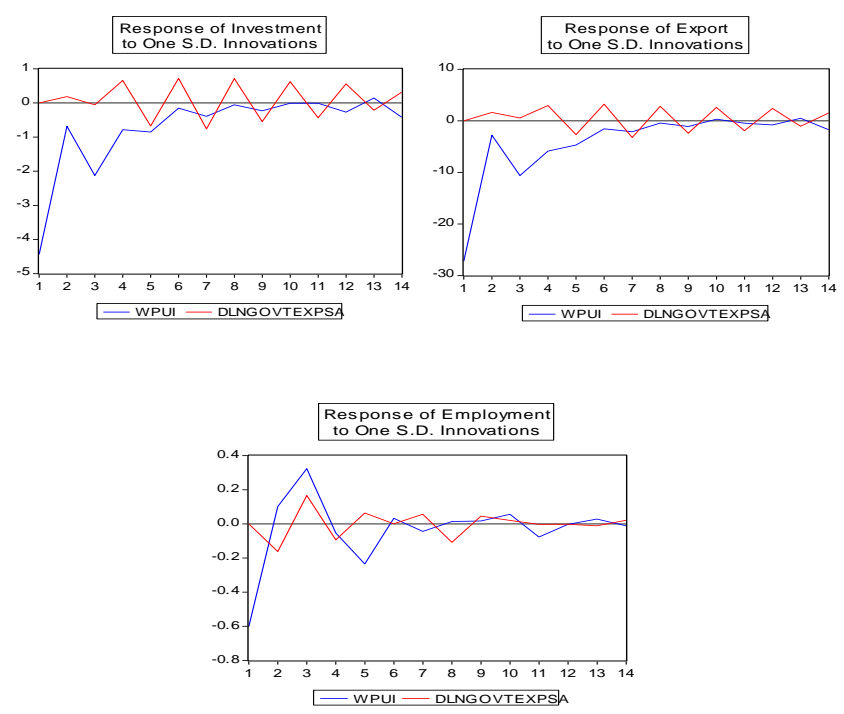

Figure 18: The Role of Expansionary Government Expenditure to Promote Investment, export and employment

\subsubsection{The Role of Reducing Import Tariffs (Import Policy) on Macroeconomic Stability}

To enhance the potency expansionary fiscal policy intervention to stabilize the economy, increased public expenditure has to be complemented by import policies/regulations/procedures. An important instrument of expansionary fiscal policy in this regard is reducing import tariffs. Reduction of tariff should be directed toward key ventures in the supply chain in the import supply of consumption and investment goods.

The role of import policies to complement fiscal policy measures can be explained in to two. For one, by reducing the transaction cost in import sector, complementary import policies would have positive spillover effect in final prices thereby mitigating inflation. On the other hand, complementary import policies would help facilitate importing consumption and investment goods, hence mitigate the inflationary effects of expansionary fiscal policy by keeping the balance of aggregate demand and supply.

The role of import policy to stabilize prices is depicted in the IRF graphs below 

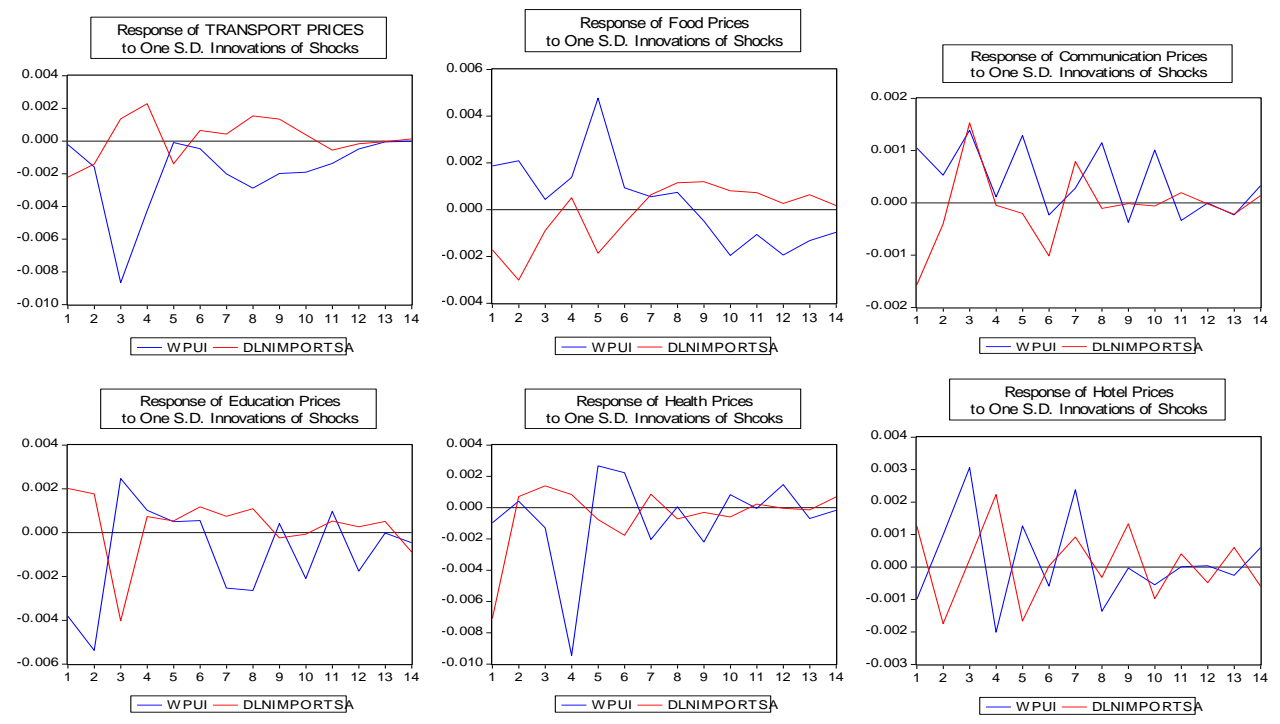

Figure 19: The Role of Import Policies to stabilize prices (both food and non-food Prices)

Beyond its price stabilization outcomes, a managed and viable import policy can also have positive outcome in spurring investment and export, hence widening employment opportunities in the economy (see IRF graphs below).
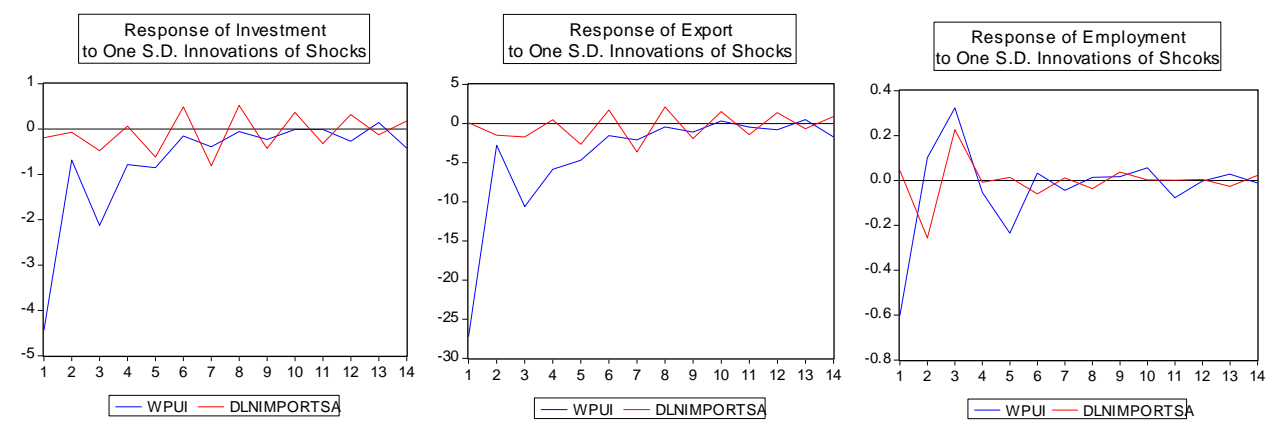

Figure 20: The Role of Import Policies to Promote Investment, export and employment 


\section{CONCLUSION AND POLICY RECOMMENDATIONS}

This study investigated the impact of COVID-19 pandemic uncertainty shock on the macroeconomic stability of Ethiopia. The World Pandemic Uncertainty Index (WPUI) was used a proxy variable to measure COVID-19 Uncertainty shock effect. The pandemic effect on core macroeconomic variables like investment, employment, prices (both food \& non-food prices), import, export and fiscal policy indicators was estimated and forecasted. The role of fiscal policy in mitigating the shock effect of coronavirus pandemic on macroeconomic stability is also investigated.

\subsection{Conclusion}

The finding of the study reveals that the COVID-19 impact lasts at least three years to shake the economy of Ethiopia.

Essentially the COVID-19 immediate impact was on international transactions, and in the Ethiopian context, where the country relies heavily on import for the service of consumption and investment demands. Hence, the impact is expected to take its toll via import channel in the immediate aftermath of the outbreak of the pandemic.

The VAR estimate indicates that COVID-19 uncertainty shock results a massive rise in import in the six months following the outbreak of the pandemic. The finding in this regard is expected, as the pandemic triggers massive demand in food and pharmaceuticals, for which Ethiopia is import dependent on both items. In the next two years, however, the import bill of Ethiopia shows a decline. Reduction in aggregate demand (both consumption \& investment expenditures) is one explanation for decline in import size in 2013 and 2014 E.C.

The price dynamics as forecasted in the upcoming three years in Ethiopia tells the direction of impacts of COVID-19 uncertainty shock to shake the macroeconomic order. The findings in this regard revealed the structural breakups of Ethiopian economy, characterized by its inability to withstand shocks. As signaled in forecasted price dynamics on both food and non-food price indices, COVID-19 was a supply shock in its first time impact, but quickly trans-passes to demand shock. And in the next few years the demand shock outweighs the supply shock. 
The results of estimations indicate that food prices to sky rocketed at least until the end of 2014 E.C (2021/22). On the other hand, except communication \& hotel \& restaurant prices, other components of non-food price indices show a slump. The decline in non-food price level is a clear showcase of under-consumption characterizes the economic order in Ethiopia in the coming three years.

COVID-19 uncertainty shock puts huge loss in the investment sector in Ethiopia at least in the coming two years 2013 and 2014 E.C (2020/21-2021/22). In this regard, the pandemic effect transmitted to shake investment expenditure via the length of the pandemic period itself and export performances, both of which are exogenous shocks.

Employment declines up until the sixth quarter, but shows a slight increase between the sixth and eighth quarter of forecast. The uncertainty impact of COVID-19 on employment dies-off after the tenth quarter. The finding of the study further reveals that price stabilization policies both in food and non-food markets are integral elements in promoting investment.

Findings from VAR estimation suggest that fiscal policy can help stabilize both food and nonfood prices in the next three years at least. A particular role of government spending in stabilizing prices goes to food market and in the transport sector. Moreover, the study found out that price stabilization policies have spillover effects in boosting investment, promote export and enhancing the scope of the economy in terms of creating employment opportunities.

\subsection{Policy Recommendations}

The study identified that general under consumption features the Ethiopian economy in the next couple of years. Therefore, the government is expected to enact incentives/policy directions which can boost business confidence. In this regard, government expenditures on consumption and capital goods would heal the damage cost of COVID-19 uncertainty shocks on aggregate demand thereby promoting investment \& consumption expenditures. The finding of the study suggests for a managed expansionary fiscal policy to promote investment induced employment and stabilize food \& non-food prices.

Policies that aim to stabilize food price should focus in providing economic incentives to those agents in food supply chain thereby increasing their production capacity. Price stabilization 
interventions in the food market can also be achieved through strategies that identify key agents in the supply chain most affected by the pandemic shock, and channel subsidies in those lines

Moreover, the government has to encourage merchandise imports to avoid inflationary effects of expansionary fiscal policy in basic consumption and investment goods as a result of supply shortfalls. In this regard, incentivizing the transport and logistics sector can help fix major fallouts of the economy as result of COVID-19 uncertainty shock effect on supply chain. Policy interventions can manage on that through combined legal, bureaucratic and financial policies/strategies/directives that helps facilitate for an efficient export-import trade, which is key to mitigate macroeconomic instability thereby narrowing the gap in aggregate demand and supplies on consumption and investment goods.

Finally, while servicing its rising expenditures, the government has to see viable options of financings. As such, financing public expenditures should be in a way that would not pressurize the prospect of the economy in medium and long run. As part of the broader interventions in the economy through divergent policy instruments, fiscal optimization should also be considered in a way retargeting or reprogramming possible on already running public projects/programs when the need arises. 


\section{REFERENCES}

African Union (AU). 2020. Impact of the Coronavirus (COVID-19) on the African Economy, March.

Africanews. 2020. Coronavirus 'corroding' sports betting in East Africa, March

Alebel Bayrau Weldesilassie and Tassew Woldehanna. 2020. The Economic Implications of COVID - 19 in Ethiopia and Policy Measures, Policy Studies Institute (PSI), Addis Ababa, Ethiopia, April

Alemayehu Geda. 2020.The Macroeconomic and Social Impact of COVID-19 in Ethiopia and Suggested Directions for Policy Response, Preprint, April

Baker, Scott R., Nicholas Bloom, Terry, Stephen J. 2020. Using Disasters to Estimate the Impact of Uncertainty, Northwestern University Kellogg School of Management and NBER, Stanford University and Boston University

Baldwin, R. and Weder di Mauro B. 2020. Economics in the Time of COVID-19, Centre for Economic Policy Research (CEPR), CEPR E-Book, ISBN: 978-1-912179-28-2, CEPR Press, London, UK, March

Bronwyn Bruton. 2020. What does the coronavirus mean for Africa?, REUTERS, March

Doan, Thomas, Robert Litterman, and Christopher Sims. 1984. Forecasting and Conditional Projection using Realistic Prior Distributions," Econometric Reviews, Vol. 3, No. 1, pp. 1\{100.

Fetzer, T., Hensel, Lukas., Hermle, J. Roth. 2020. Coronavirus Perceptions And Economic Anxiety, First version, March

FDRE Ministry of Finance and Cooperation. 2020. COVID-19 Multi-Sectorial Preparedness \& Response Plan, Addis Ababa, April

International Monitory Fund (IMF). 2018. Country Report No. 18/354, The Federal Democratic Republic of Ethiopia, Pp. 4, December 
Jordà, Òscar, Sanjay R. Singh, Alan M. Taylor. 2020. "Longer-Run Economic Consequences of Pandemics," Federal Reserve Bank of San Francisco Working Paper 2020-09. https://doi.org/10.24148/wp2020-09

Miranda-Agrippin, S. and Ricco, G. 2018. Bayesian Vector Auto-regressions, Bank of England and CFM and University of Warwick and OFCE - SciencesPo

Kuikeu, Oscar. 2020. Economic impact of COVID-19 in Cameroon: an empirical assessment with the VAR Methodology, April

Litterman, Robert B. 1979. Techniques of forecasting using vector auto-regressions, Working Papers 115, Federal Reserve Bank of Minneapolis.

Liu, S. 2020. The Butterfly Effect: Coronavirus may Re-define the Global Currency Landscape. Harvard Kennedy School.

Ozili, P. 2020. Covid-19 Pandemic and Economic Crisis : The Nigerian experience and Structural causes. https://ssrn.com/abstract=3571085, April.

POLITICO Magazine. 2020, Coronavirus Will Change the World Permanently. Here's How: A crisis on this scale can reorder society in dramatic ways, for better or worse. Here are 34 big thinkers' predictions for what's to come, March

PINSHI, Christian P. 2020. COVID-19 uncertainty and monetary policy, University of Kinshasa, May

Tadele Ferede, Getachew Diriba and Lulit Mitik Beyene. 2020. The economy wide impact of the COVID-19 in Ethiopia: Policy and Recovery options'. Ethiopian Economics Association (EEA), June

The Economist Magazine. 2020. The 90\% Economy that Lockdowns will leave Behind, April.

United Nations Conference on Trade and Development (UNCTD). 2020. The Covid-19 Shock to Developing Countries: Towards a "whatever it takes" program for the two-thirds of the world's population being left behind, March 
Watanabe, T. 2020. The Responses of Consumption and Prices in Japan to the COVID-19 Crisis and the Tohoku Earthquake. JSPS Grant-in-Aid for Scientific Research (S), Central Bank Communication Design, working paper series no.020, March.

Yeshineh and Alfredo J. Mainar Causapé. 2020. Ethiopia: Input-Output Table and Social Accounting Matrix 2015/16, Policy Studies Institute (PSI), Addis Ababa, Ethiopia 